September 2014

\title{
UNDERSTANDING NEW RESOURCE PROJECTS
}

\author{
by \\ Kenneth W Clements, Jiawei Si and Thomas Simpson* \\ Business School \\ The University of Western Australia
}

\begin{abstract}
$\underline{\text { Abstract }}$
The surge in new resource projects has been a prominent feature of the recent strong performance of the Australian economy, with mining and energy investment accounting for almost one-half of all private investment. Although the current round of resource investment has now peaked, as resource cycles tend to repeat themselves, there is an ongoing need to carefully understand the available information sources. We use a specially developed panel of matched projects from three widely followed, but under-researched, sources to analyse cost inflation, the biases, the degree of independence and timeliness of each source. This information is of use to policy makers who have to closely monitor these developments, analysts following the resources sector, and project proponents wanting to know something about the typical cost profile of a project.
\end{abstract}

\footnotetext{
* For comments and help, we thank Adrian Arundell, Aiden Depiazzi, Grace Gao, Peter Hartley, Liang Li and seminar participants at UWA and the Economic Measurement Group Workshop, Sydney, 2013. We are grateful to Steve Smith, from Deloitte Access Economics, for providing us with their Investment Monitor subscription database and responding to our inquiries. This research was supported in part by the Australian Research Council, BHP Billiton and the UWA Business School. All errors are our own.
} 


\section{Introduction}

High commodity prices over the last decade or so have led to an unprecedented resources boom in Australia. This has stimulated a large-scale program of investments in new resource prospects that, in part at least, helped Australia avoid recession and perform better than most other high-income countries. As a result, analysts of the Australian economy now give considerable prominence to information on resource investment plans. As some resource projects are very large, the nature of their cost is of considerable relevant to public policy regarding infrastructure. A recent inquiry by the Australian Productivity Commission into public infrastructure has highlighted the inadequacy of presently available project data to systematically explain the source and nature of cost pressures, hampering accurate cost projections and optimal investment decisions (Productivity Commission, 2014). Internationally, there is considerable evidence of serious problems with investment in "megaprojects" as they suffer from widespread over optimism, cost overruns and delays (Flyvbjerg, 2009, 2014). Flyvbjerg $(2009,2014)$ goes so far as to describe the situation as one where "the worst projects get built".

This paper helps to deepen the understanding of project costs by identifying the strengths and weaknesses of three data sources of Australia resource projects that have tended to be under used in research in the past. The three sources are: The WA Department of State Development's Prospect Magazine, Deloitte Access Economics' Investment Monitor subscription database and the ABARES/BREE Mining Projects database. ${ }^{1}$ Using a unique database in which projects are matched across these sources, we analyse the quality and usefulness of these data.

The structure of the paper is as follows. The next section describes the process of matching projects across the three sources. The matched data mean there are three readings on the cost of each project through time, from which preliminary estimates of the biases are obtained. Section 3 uses these rich data to construct a hedonic index of cost escalation that is not contaminated by the entry and exit of radically different projects, each with their own inflation rate. The hedonic model also leads to more refined estimates of biases in the three sources. Later sections deal with understanding the pattern of information flows regarding cost escalation and an analysis of the degree to which sources rely on each other. The

\footnotetext{
${ }^{1}$ Details of the ABARES/BREE source are as follows. This is the Bureau of Resources and Energy Economics' publication "Resources and Energy Major Projects". Before July 2011, this publication was the Australian Bureau of Agricultural and Resource Economics and Sciences' "Minerals and Energy Major Development Projects". For brevity, the ABARES/BREE publications will be referred to as BREE.
} 
estimates of the cost of a project made before its conclusion can be considered as a forecast of the final cost, and the quality of these forecasts is investigated towards the end of the paper. The paper concludes with an overall assessment of the three sources.

\section{Matching Projects}

To qualify for inclusion in our matched database, a project has to have at least one period of capital expenditure reported contemporaneously in all three sources. Projects that had triplicate matches in some periods but not others are included only for the matching periods. $^{2}$ The included projects are usually those that attract more attention from the various stakeholders, that is, the larger ones. The period covered is September 2006 to September 2012. Table 2.1, which summarises the matched data, clearly shows this as the mean project size (as measured by cost, termed "capex" in the table) is of the order of $\$ A 3.5 b$ (second last row of the table). In total, 354 triplets of projects are matched and Table 2.1 gives the number per period.

The last three columns of Table 2.1 compare the cost in each of the three sources in the form of deviations from the overall mean. The second last element of the column for Prospect (column 10) reveals that according this source, the size of projects is lower, on average, by more than $\$ 100 \mathrm{~m}$ than the overall mean. On the basis of a t-test, this difference is significant (see the last entry of this column). The bias is in the opposite direction for BREE projects, which are larger, on average, by about $\$ 100 \mathrm{~m}$ (also significant). The Investment Monitor (IM) data are approximately unbiased. As the projects are matched exactly, these differences cannot be attributed to differing coverage of the three sources. Of course, in the context of a project costing $\$ 3.5 \mathrm{~b}$, a $\$ 100 \mathrm{~m}$ error is less than 3 percent, so the economic significance is modest.

The second last row of Table 2.1 also shows that the dispersion, as measured by the standard deviation, of projects in $\underline{\mathrm{IM}}$ and BREE are very similar, while that of Prospect is somewhat lower. The correlations among the three sources are high (at least 0.98, as indicated in the notes to the table), which is to be expected as the same projects are involved and, most likely, each source looks at its two neighbours. More will be said about this later. Figure 2.1 provides a visual comparison of the data by giving the three pairwise contrasts. The clustering of observations around the 45-degree lines illustrates the substantial agreement across sources. But still for the BREE/Prospect contrast in the south-east quadrant, there is a noticeable tendency for the points to lie below the 45-degree line, reflecting the underpricing

\footnotetext{
${ }^{2}$ Refer to the Appendix for further discussion of the data.
} 
in Prospect and overpricing in BREE. The high root mean square errors (RMSEs) of each quadrant, which are of the order of 30 percent, show a reasonably large degree of crosssource variance. In summary, although project values are highly correlated, there is still a significant difference between Prospect and BREE.

\section{Hedonic Costing}

Next, we use the matched data to estimate a hedonic model of the form $\log v_{i t}^{s}=\gamma^{s}+\lambda_{i}+\theta_{t}+\varepsilon_{i t}^{s}, \quad s=1,2,3 ; i=1, \ldots, N_{t} ; t=1, \ldots, 13$.

Here, $\mathrm{v}_{\mathrm{it}}^{\mathrm{s}}$ denotes capex from source $\mathrm{s}(\mathrm{s}=1,2,3$, representing Prospect, $\underline{\mathrm{IM}}$ and BREE, respectively) in period $t(t=1, \ldots, 13)$ for project $i\left(i=1, \ldots, N_{t}\right)$. This capex depends on source effects, $\gamma^{\mathrm{s}}$, that allow for the biases in the three publications; projects effects, $\lambda_{i}$, to control for projects that differ in nature and scale; time effects, $\theta_{t}$, to capture cost escalation (time is measured in half-yearly intervals, from September 2006 to September 2012); and random factors as measured by the disturbance term $\varepsilon_{i t}^{\mathrm{s}}$. The project effects allow for projects with different idiosyncrasies entering and dropping out of the system. The estimates of the time effects provide an index of cost escalation that measures "pure" inflation that in no way reflects extraneous influences. Similarly, estimated source biases are insulated from compositional issues.

The estimates of the hedonic model are given in Table 3.1. Across all projects, the annual rates of cost escalation in column 2 are highly significant, but there are some noticeable year-to-year fluctuations. Over the whole period, project cost escalation averages about 13 percent p.a., which is much larger than CPI inflation over the same period. ${ }^{3}$ According to the estimated source effects (column 2), the costs of projects in Prospect are understated by about 5 percent, those in BREE overstated by 4 percent (and both estimates are significant), while for $\underline{\mathrm{IM}}$ the bias is positive but insignificantly different from zero. These results broadly agree with those of Figure 2.1.

We also split the 74 projects into three equal sized groups $(25,25,24)$ based on their average starting cost. The year-to-year cost escalation for small projects (column 3) is largely insignificant but on average costs increase by 8 percent p.a., which is significant. The majority of cost escalations for large and mega projects (columns 4 and 5) are statistically

\footnotetext{
${ }^{3}$ The average logarithmic difference $(\times 100)$ of the CPI from September 2006 to September 2012 is $2.8 \%$ p.a. Source: ABS Cat No. 64010.0.
} 
significant with the average change around 13 percent p.a. and 16 percent p.a., respectively. Prospect also continues to understate costs and BREE continues to overstate for large and mega projects. The source effects are the most extreme for large projects, where Prospect understates costs by 9.3 percent and IM and BREE overstate by 5.7 percent and 3.6 percent, respectively. For small projects, none of the source effects is significant.

Lastly, we repeat the analysis for the projects based on the industry (LNG, Iron Ore or Others) they belong to in columns 6 to 8 of Table 3.1. Apart from the year-to-year fluctuations, LNG and Iron Ore projects have an average cost escalation of about 15 percent p.a., while costs rise by 8 percent for those in Other industries, all of which are significant. The source bias of IM continues to be bracketed by Prospect and BREE for both the LNG and Iron Ore industries, whilst the source biases are insignificant for Other industries. The degree of underestimation in Prospect is more substantial for Iron Ore projects compared to LNG ( -9 percent vs. -5.5 percent); likewise, BREE overstates costs slightly more for Iron Ore projects (6.3 percent) as compared to LNG projects (5.5 percent).

These hedonic results provide some insight into the pressures faced by the resources sector during the recent boom: If, on average, the cost of a project rises by, say, 15 percent p.a., after six years the cumulative escalation is almost 150 percent. Cost escalations are prevalent for all types of projects on average, but are substantially greater the larger ones, which tend to be in the LNG and Iron Ore industries. This is consistent with evidence presented by Flyvberg (2014) that initial project costs are substantially understated. Regarding source biases, project costs in Prospect are understated, BREE overstates them and $\underline{I M}$ is usually bracketed between the other two.

\section{Modelling Information Flows}

The three sources of capex data refer to the same projects, but in many instances report different values. Over time, it might be expected that the values converge through a Darwinian process of "good information driving out bad". Suppose, for example, that source 2 initially has more accurate data on a certain project than source 1. Then, the "updating" process could be direct in the form of source 1 using previously published data by source 2 with a lag, which we can write as $2 \rightarrow 1$. This situation would also occur when source 2 responds rapidly to new information on the project, while 1 responds only slowly. Although there is no overt copying of one source by another, as it is observationally equivalent, the process can still be described as $2 \rightarrow 1$. The process could also be indirect involving a third source of the form $2 \rightarrow 3 \rightarrow 1$, a sequence that might extend over a longer period. For other 
projects, the reverse situation may apply with source 1 being more accurate than 2 , so when all projects are considered together, there would be a two-way flow of information. In this section, we use a VAR model to measure this type of information exchange. This approach considers flows in all directions and sheds some light on which sources tend to excel in publishing new information.

Let $\mathrm{g}_{\mathrm{it}}^{\mathrm{s}}=\log \left(\mathrm{v}_{\mathrm{it}}^{\mathrm{s}} / \mathrm{v}_{\mathrm{i}, \mathrm{t}-1}^{\mathrm{s}}\right)$ be the revision, or growth rate, in the projected capex $\mathrm{v}_{\mathrm{it}}^{\mathrm{s}}$ for project $\mathrm{i}$ from period $\mathrm{t}-1$ to $\mathrm{t}$ according to source $\mathrm{s}$. The $3 \times 1$ vector of growth rates for project $\mathrm{i},\left[\mathrm{g}_{\mathrm{it}}^{1}, \mathrm{~g}_{\mathrm{it}}^{2}, \mathrm{~g}_{\mathrm{it}}^{3}\right]^{\prime}$, is taken to be a first-order vector autoregressive process, the $\mathrm{s}^{\text {th }}$ member of which is

$$
\mathrm{g}_{\mathrm{it}}^{\mathrm{s}}=\alpha_{\mathrm{i}}^{\mathrm{s}}+\sum_{\mathrm{r}=1}^{3} \beta_{\mathrm{i}}^{\mathrm{sr}} \mathrm{g}_{\mathrm{i}, \mathrm{t}-1}^{\mathrm{r}}+\varepsilon_{\mathrm{it}}^{\mathrm{s}},
$$

where $\alpha_{i}^{\mathrm{s}}$ and $\beta_{\mathrm{i}}^{\mathrm{sr}}$ are coefficients and $\varepsilon_{\mathrm{it}}^{\mathrm{s}}$ is a disturbance term. The intercept $\alpha_{\mathrm{i}}^{\mathrm{s}}$ measures the role of other sources of cost escalation that occur independent of the past; these can be called "autonomous" cost increases. The own-coefficient $\beta_{i}^{\text {ss }}$ refers to the degree to which current inflation depends on its own past history. The size of the cross-coefficient $\beta_{\mathrm{i}}^{\text {sr }}$, for $\mathrm{s} \neq \mathrm{r}$, measures the direct flow of information from source $r$ to $s$ over 1 period. Equation (4.1) for $\mathrm{s}=1,2,3$ is the VAR model for project $\mathrm{i}$.

As there is insufficient time-series data to estimate model (4.1) for each of the 74 distinct projects, we pool the data by taking the coefficients to be the same over projects to estimate

$$
\mathrm{g}_{\mathrm{it}}^{\mathrm{s}}=\alpha^{\mathrm{s}}+\sum_{\mathrm{r}=1}^{3} \beta^{\mathrm{sr}} \mathrm{g}_{\mathrm{i}, \mathrm{t}-1}^{\mathrm{r}}+\varepsilon_{\mathrm{it}}^{\mathrm{s}} .
$$

for $\mathrm{s}=1,2,3$. Panel A of Table 4.1 uses that matched data to estimate this model. ${ }^{4}$ Looking at the first row that refers to Prospect, the estimate of the intercept is 0.050 , which means that autonomous inflation according to this source is about 5 percent per half year (and significant). Next, the estimate of the own autoregressive coefficient, $\beta^{11}$, is -0.043 . The negative sign means that higher inflation last period tends to be followed by lower inflation in this period, other things remaining unchanged. Thus, rather than inflation inertia, there is some degree of mean reversion in the level of capex. However, this coefficient is relatively small and not significantly different from zero. The estimated cross-lag coefficient $\beta^{13}$ of

\footnotetext{
${ }^{4}$ See Clements et al. (2014) for further details.
} 
0.115 implies that about 12 percent of past growth in costs in BREE passes through into current growth in costs reported in Prospect. This estimate is significant and considerably larger than that for $\underline{\mathrm{IM}} \rightarrow \underline{\text { Prospect }}\left(\hat{\beta}^{12}\right)$. Thus, there is a more substantial flow of information from BREE to Prospect, than from IM. The estimates of the coefficients of the two other equations have a similar interpretation.

The F-statistics in column 8 of the table test the hypothesis of all the three lagged source coefficients are jointly zero. The null is rejected in the case of both $\underline{\mathrm{IM}}$ and BREE, but not for Prospect. The last column tests if in each case, the two alternate sources play no role. BREE has a lower F-value than IM, suggesting the possibility that BREE is informed less by the other sources than is $\underline{\mathrm{IM}}$, and may rely more on its own research to revise its data. Further results below would also seem to point to this conclusion.

As discussed in the App, there are slight asynchronies in the dates of the publication of the three sources that may in part explain the result of Table 4.1 that BREE appears to be more influenced by $\underline{\mathrm{IM}}$ than vice versa (that is, $\hat{\beta}^{32}>\hat{\beta}^{23}$ ).

The insignificant F-value for Prospect in the last column of panel A of Table 4.1 means that other sources play no role in contributing to this publication. Taken in isolation, the interpretation of this result is ambiguous. It could be that Prospect is the "market leader" in disseminating new information and does not need to absorb information from the other sources. Alternatively, it could be that they do not go to the trouble of "learning" from the other sources. From the second and third rows of columns 3-5 of Table 4.1, both $\underline{\mathrm{IM}}$ and BREE appear to take on less information from Prospect than from the other sources $\left(\hat{\beta}_{21}<\hat{\beta}_{23}, \hat{\beta}_{31}<\hat{\beta}_{32}\right)$; this would seem to point to Prospect not being the market leader. Coupled with Prospect's systematic bias noted above, the indications are that Prospect does not seem to lead in information dissemination, but is somewhat divorced from the system as a whole. This conclusion is reinforced by the extremes of the cross-effects coefficients: In absolute terms, the smallest is for $\underline{\mathrm{IM}} \rightarrow \underline{\text { Prospect }}\left(\hat{\beta}^{12}=0.017\right)$, while the largest is $\underline{\mathrm{IM}} \rightarrow$ $\operatorname{BREE}\left(\hat{\beta}^{32}=0.210\right)$. That is, $\underline{\mathrm{IM}}$ plays a minor role in the revisions to data published in Prospect, but a major one regarding BREE, pointing to the apparent "insulation" of Prospect. ${ }^{5}$

\footnotetext{
${ }^{5}$ Panel B of Table 4.1 shows the results when the intercepts are omitted from the VAR model. This has the effect of (i) decreasing (in absolute value) the own-lag coefficients, so now there is not as much mean reversion; and (ii) increasing most of the cross coefficients. But as these changes are not huge and as the general pattern
} 


\section{Bilateral and Multilateral Information Balances}

The interactions among pairs of sources in the VAR model are bidirectional. For example, from panel A of Table 4.1, information from $\underline{\mathrm{IM}}$ in the past is associated with revisions to $\operatorname{BREE}\left(\hat{\beta}^{32}=0.210\right)$, while there is also a reciprocal flow from BREE to $\underline{\mathrm{IM}}$ $\left(\hat{\beta}^{23}=0.101\right)$. The difference between these two gross flows is the net flow of $\hat{\beta}^{32}-\hat{\beta}^{23}=0.210-0.101=0.109$, which can be interpreted as saying that if costs in both sources grow by the same rate in the previous period, BREE will receive about 10 percent more information from IM than it gives in return. The flow of information is measured by that part of revision to costs in one source that can be attributed to past growth in another source, all other factors remaining unchanged. If the $3 \times 3$ matrix of estimated coefficients of the lagged terms, $\hat{\boldsymbol{\beta}}=\left[\hat{\boldsymbol{\beta}}^{\mathrm{sr}}\right]$, is symmetric, then the reciprocal trade flows are exactly equal, net flows are zero and no source is a net sender to or receiver of information from the others. Accordingly, the degree of asymmetry of $\hat{\beta}$ provides a measure of the bilateral information flows. It is convenient to formulate asymmetry with the skew symmetric matrix $\Gamma=\hat{\boldsymbol{\beta}}-\hat{\boldsymbol{\beta}}^{\prime}$. The elements of the upper triangle of this matrix, $\gamma^{\mathrm{sr}}=\hat{\beta}^{\mathrm{sr}}-\hat{\beta}^{\mathrm{rs}}, \mathrm{s}<\mathrm{r}$, give the signs of the net flows from source $\mathrm{r}$ to $\mathrm{s}, \mathrm{s}<\mathrm{r}=1,2,3$. The elements in the lower triangle are the net flows from $\mathrm{r}$ to $\mathrm{s}, \gamma^{\mathrm{sr}}=\hat{\beta}^{\mathrm{sr}}-\hat{\beta}^{\mathrm{rs}}, \mathrm{s}>\mathrm{r}$, which are the negative of those in the upper triangle, so $\gamma^{\mathrm{sr}}=-\gamma^{\mathrm{rs}}$. In words, if $\mathrm{s}$ receives information from $\mathrm{r}\left(\gamma^{\mathrm{sr}}>0\right)$, then obviously $\mathrm{r}$ sends it to $\mathrm{s}$ $\left(\gamma^{\text {rs }}=-\gamma^{\text {sr }}<0\right)$. As a source can neither receive or send a net flow to itself, $\gamma^{\mathrm{ss}}=\hat{\beta}^{\mathrm{ss}}-\hat{\beta}^{\mathrm{ss}}=0$. The benchmark case is when $\Gamma$ contains all zero elements, as then the original coefficient matrix $\hat{\boldsymbol{\beta}}$ is symmetric and the bilateral trades are balanced.

Panel $\mathrm{C}$ of Table 5.1 gives the $\Gamma$ matrix associated with the estimates of panel A of Table 4.1 (the other two panels contain intermediate steps). The lower triangle contains the three independent measures of net flows; as these are all nonzero, bilateral trade is unbalanced. For the pairs $\underline{\mathrm{IM}} / \underline{\text { Prospect }}$ and BREE/IM, the net flows are positive, so more information is received by the former source than sent back in return. The reverse is true for 
BREE/Prospect. But as these measures have relatively large standard errors, not too much reliance can be placed on these results.

Suppose each source revises upwards in the previous period their cost data for project $\mathrm{i}$; if the revisions are equiproportional, then $\mathrm{g}_{\mathrm{i}, \mathrm{t}-1}^{1}=\mathrm{g}_{\mathrm{i}, \mathrm{t}-1}^{2}=\mathrm{g}_{\mathrm{i}, \mathrm{t}-1}^{3}=\mathrm{g}_{\mathrm{i}, \mathrm{t}-1}^{*}$. Other things remaining unchanged, the current-period revision of source $s$ is then $\mathrm{g}_{\mathrm{i}, \mathrm{t}-1}^{*} \cdot \Sigma_{\mathrm{r}=1}^{3} \hat{\beta}^{\mathrm{sr}}$. Thus, the sum of the coefficients in the row for source $s$ is proportional to its response to a "uniform" message from the three sources. The corresponding information supplied by $s$ to the others as the reciprocal flow is $\mathrm{g}_{\mathrm{i}, \mathrm{t}-1}^{*} \cdot \sum_{\mathrm{r}=1}^{3} \hat{\beta}^{\mathrm{rs}}$, implying that the net effect is $\mathrm{g}_{\mathrm{i}, \mathrm{t}-1}^{*} \cdot\left(\sum_{\mathrm{r}=1}^{3} \hat{\beta}^{\mathrm{sr}}-\sum_{\mathrm{r}=1}^{3} \hat{\beta}^{\mathrm{rs}}\right)=\mathrm{g}_{\mathrm{i}, \mathrm{t}-1}^{*} \cdot \sum_{\mathrm{r}=1}^{3} \gamma^{\mathrm{sr}}$. When $\sum_{\mathrm{r}=1}^{3} \gamma^{\mathrm{sr}}>0$, source $\mathrm{s}$ receives more information from the others than it provides, so can be described as a net importer, and vice versa. In other words, the sign of $\gamma^{\text {sr }}$ denotes the bilateral information trade balance, while that of $\Sigma_{\mathrm{r}=1}^{3} \gamma^{\mathrm{sr}}$ denotes the multilateral balance. By construction, $\Sigma_{\mathrm{s}=1}^{3} \Sigma_{\mathrm{r}=1}^{3} \gamma^{\mathrm{sr}}=0$, so world trade is balanced. The multilateral balances are contained in the last column of panel $\mathrm{C}$ of Table 5.1

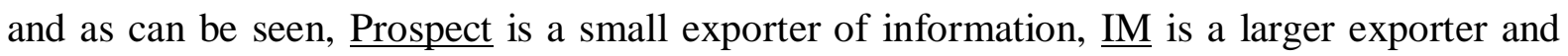
BREE is an importer. In this sense, IM would seem to be the largest contributor to the flow of new information. But due to the high standard errors, again caution should be exercised with this specific result. Further analysis of the speed of information flows using impulse response functions and a vector error correction model suggests that $\underline{\mathrm{IM}}$ and BREE respond faster to new information than Prospect. For details, see the Appendix. ${ }^{6}$

\section{Predicting Future Costs}

This section examines the ability of the estimated capital expenditure in each source to predict the subsequent actual cost of projects.

As before, for source $s$, the estimated capex of project $i$ at time $t$ is $v_{\mathrm{it}}^{\mathrm{s}}$. If construction of the project is completed at time $T_{i}$, this estimated cost is to be compared with the final cost denoted by $v_{i, T_{i}}^{s}$; this final, or actual, cost is observed $T_{i}-t=h$ periods in the future from $t$. The estimated cost can also be formulated in terms of the forecast horizon $h$ as $v_{i, T_{i}-h}^{s}$.

\footnotetext{
${ }^{6}$ Another metric of the quality of information is its timeliness, as measured by the frequency and nature of cost revisions. We find that BREE is updated substantially more frequently than the other two sources; however, $\underline{I M}$ adds more unique information in its updates. For details, see the Appendix.
} 
If there are $N_{h}$ projects having horizon $h$, then the logarithmic mean forecast error at $h$ and the corresponding standard deviation are

$$
\mathrm{B}_{\mathrm{h}}^{\mathrm{s}}=\frac{1}{\mathrm{~N}_{\mathrm{h}}} \sum_{\mathrm{i}=1}^{\mathrm{N}_{\mathrm{h}}}\left(\log \mathrm{v}_{\mathrm{i}, \mathrm{T}_{\mathrm{i}}}^{\mathrm{s}}-\log \mathrm{v}_{\mathrm{i}, \mathrm{T}_{\mathrm{i}}-\mathrm{h}}^{\mathrm{s}}\right), \quad \mathrm{SD}_{\mathrm{h}}^{\mathrm{s}}=\sqrt{\frac{1}{\mathrm{~N}_{\mathrm{h}}} \sum_{\mathrm{i}=1}^{\mathrm{N}_{\mathrm{h}}}\left(\log \mathrm{v}_{\mathrm{i}, \mathrm{T}_{\mathrm{i}}}^{\mathrm{s}}-\log \mathrm{v}_{\mathrm{i}, \mathrm{T}_{\mathrm{i}}-\mathrm{h}}^{\mathrm{s}}-\mathrm{B}_{\mathrm{h}}\right)^{2}} .
$$

These measures, for each source, are used as the basis for the fan charts of panels A, B and C of Figure $6.1 .^{7}$ For each source, the mean errors are mostly positive, indicating a bias to underestimate costs. ${ }^{8}$ The bias, however, declines with the horizon from about 5-10 percent for a two-year horizon to -2 to 1 percent for six months out. The error bands also shrink noticeably with the horizon; for $\mathrm{h}=4$, for example, the two-standard-error band is about \pm 10 percent, while for $\mathrm{h}=1$, it is smaller by a factor of almost 10 . As to a first approximation these patterns apply to all three sources, they provide little basis for choosing between them. Panel D of Figure 6.1 will be discussed subsequently.

Rather than taking each source by itself as a predictor, we now consider a composite forecast made up of all three together. We start with a regression of actual on estimated capex for source s and horizon h:

$$
\log \mathrm{v}_{\mathrm{i}, \mathrm{T}_{\mathrm{i}}}^{\mathrm{s}}=\alpha_{0}^{\mathrm{s}}+\alpha_{1}^{\mathrm{s}} \log \mathrm{v}_{\mathrm{i}, \mathrm{T}_{\mathrm{i}}-\mathrm{h}}^{\mathrm{s}}+\varepsilon_{\mathrm{i}}^{\mathrm{s}}, \quad \mathrm{i}=1, \ldots, \mathrm{N}_{\mathrm{h}},
$$

where $\varepsilon_{\mathrm{i}}^{\mathrm{s}}$ is a random disturbance. The forecasts are said to be unbiased if the intercept $\alpha_{0}^{\mathrm{s}}=0$ and efficient if the slope coefficient $\alpha_{1}^{\mathrm{s}}=1$ (Mincer and Zarnowitz, 1969). Averaging both sides of this equation over sources gives

$$
\log \mathrm{v}_{\mathrm{i}, \mathrm{T}_{\mathrm{i}}}=\beta_{0}+\sum_{\mathrm{s}=1}^{3} \beta_{1}^{\mathrm{s}} \log \mathrm{v}_{\mathrm{i}, \mathrm{T}_{\mathrm{i}}-\mathrm{h}}^{\mathrm{s}}+\varepsilon_{\mathrm{i}}, \quad \mathrm{i}=1, \ldots, \mathrm{N}_{\mathrm{h}},
$$

where $\log \mathrm{v}_{\mathrm{i}, \mathrm{T}_{\mathrm{i}}}=(1 / 3) \sum_{\mathrm{s}=1}^{3} \log \mathrm{v}_{\mathrm{i}, \mathrm{T}_{\mathrm{i}}}^{\mathrm{s}}$ is averaged actual cost, $\beta_{0}=(1 / 3) \sum_{\mathrm{s}=1}^{3} \alpha_{0}^{\mathrm{s}}$ is the averaged intercept, $\beta_{1}^{\mathrm{s}}=\alpha_{1}^{\mathrm{s}} / 3$ is one-third of the slope coefficient in equation (6.1), $\mathrm{s}=1,2,3$, and $\varepsilon_{\mathrm{i}}=(1 / 3) \Sigma_{\mathrm{s}=1}^{3} \varepsilon_{\mathrm{i}}^{\mathrm{s}}$ is the averaged disturbance. ${ }^{9}$ The term $\sum_{\mathrm{s}=1}^{3} \beta_{1}^{\mathrm{s}} \log \mathrm{v}_{\mathrm{i}, \mathrm{T}_{\mathrm{i}} \mathrm{h}}^{\mathrm{s}}$ on the right of equation (6.2) can regarded as a composite forecast; unbiasedness and efficiency of this composite requires $\beta_{0}=0, \Sigma_{\mathrm{s}=1}^{3} \beta_{1}^{\mathrm{s}}=1$.

\footnotetext{
${ }_{8}^{7}$ For details of the data used in this section, see Clements et al. (2014).

${ }^{8}$ The tendency to underestimate project costs has been noted by others. See, e. g., Flyvbjerg et al. $(2009,2014)$.

${ }^{9}$ In most cases, "actual" capex differs by source, probably because sources update their data at different speeds. Taking the average reduces the random components of the "actuals"; and, of course, when actual is the same in each source (which occurs for some projects), the average is the common value. It is worthwhile noting that there does not seem to be any particular tendency for poor prediction to be associated with projects with diverse actuals.
} 
Table 6.1 gives the estimates of equation (6.2) for four horizons and several features should be noted. First, the estimates of the intercepts for all four horizons are positive and three are insignificant. This indicates the forecasts when combined in this manner are approximately unbiased and agrees with Figure 6.1, where the error bands mostly span the zero line. Second, in all but one out of the twelve cases, the estimated slope coefficients are positive, so each source usually makes a positive contribution to the composite forecast. Third, as column 6 shows that the sums of the slope coefficients are insignificantly different from unity, it can be concluded that the composite forecast is also efficient. Finally, from columns 10 and 11 , there is no strong evidence against the hypothesis of equal slope coefficients, so that the three sources can be equally weighted to form the composite.

Based on these results, we set the intercept in equation (6.2) to zero and the slope coefficients to $1 / 3$. Thus, the composite becomes the unweighted mean of the three sources:

$$
\log \mathrm{v}_{\mathrm{i}, \mathrm{T}_{\mathrm{i}}}=\log \mathrm{v}_{\mathrm{i}, \mathrm{T}_{\mathrm{i}}-\mathrm{h}}+\xi_{\mathrm{i}} \text {, with } \log \mathrm{v}_{\mathrm{i}, \mathrm{T}_{\mathrm{i}}-\mathrm{h}}=\sum_{\mathrm{s}=1}^{3}(1 / 3) \log \mathrm{v}_{\mathrm{i}, \mathrm{T}_{\mathrm{i}}-\mathrm{h}}^{\mathrm{s}}, \quad \mathrm{i}=1, \ldots, \mathrm{N}_{\mathrm{h}},
$$

where $\xi_{\mathrm{i}}$ is the forecast error. Panel D of Figure 6.1 contains the corresponding fan chart and it can be seen that the averaging procedure decreases the width of the error bands noticeably - by at least 40 percent in seven of the twelve cases. In other words, averaging leads to a considerable increase in forecast precision. Columns 11-13 of Table 6.2 confirms that model (6.3) performs reasonably satisfactorily: For a two-year horizon, the mean error is about 8 percent and the RMSE is 18 percent, while for six months these fall to near zero and slightly less than 3 percent, respectively. ${ }^{10}$

\section{Summary and Conclusions}

The resources sector (mining and energy) has been a prominent contributor to Australia's recent strong economic performance. As estimates of future investment in resource projects are carefully monitored as an indicator of the likely future course of the Australian economy, it is surprising that there is little research assessing the quality of this information. In this paper, we examined carefully three such sources: The Western Australian Department of State Development's Prospect Magazine, Deloitte Access Economics' Investment Monitor subscription database and the ABARES/BREE Mining Projects database (which, for simplicity, we refer to as just "BREE").

The results of the paper provide guidance regarding how the sources should be assessed and ranked. Table 7.1 provides a convenient summary of the key results. From panel

${ }^{10}$ Table 6.2 also contains the corresponding error statistics for each of the three sources. 
A, there are significant differences in the estimates of capital expenditure in the three sources, with those in Prospect the cheapest, on average, and those in BREE the most expensive. Panel B shows that the bias in Prospect is about -5.4 percent, while that for BREE is 3.6 percent. While modest, these are significantly different from zero. The Investment Monitor (IM) is approximately unbiased. IM also distinguishes itself as being the largest net exporter of information (row 8 of the table).

There are some additional important features of the three sources that should also be mentioned: BREE presents some difficulties in tracking projects over time as it does not assign a unique number to each project and also has the problem of referring to the same project by different names at different times. Prospect and BREE are provided free of charge by government, whereas $\underline{\mathrm{IM}}$ costs $\$ 1,210$ for four issues (or $\$ 616$ for a single issue). Another feature is timeliness and coverage: Prospect is published biannually and deals with major projects in the state of WA (the location of the majority of projects); and IM and BREE are quarterly and report Australian projects. Finally, as discussed in Clements et al. (2014), $\underline{\mathrm{IM}}$ attracts more media attention than BREE (and Prospect, which has a very low media presence), but BREE is a more recent product that is growing rapidly (in terms of citations).

Taken as a whole, the above considerations mean that $\underline{\mathrm{IM}}$ is most likely the preferred source. This conclusion is reinforced by the finding that the updates to the $\underline{\mathrm{IM}}$ data contribute more unique information relative to the other two sources (see the Appendix for details). Thus, in this sense, it is true that "you get what you pay for".

\section{$\underline{\text { References }}$}

Clements, K. W., and J. Si (2010). "The Investment Project Pipeline: Cost Escalation, LeadTime, Success, Failure and Speed." Australian Journal of Management, 36 (3): 317-48.

Clements, K. W., J. Si and T. Simpson (2014). "Understanding New Resource Projects." Economics Discussion Paper 14.17, UWA Business School. http://www.business.uwa.edu.au/_data/assets/pdf_file/0005/2530058/14.17Understanding-New-Resource-Projects.pdf

Flyvbjerg, B. (2009). "Survival of the Un-fittest: Why the Worst Infrastructure Gets Built and What We Can Do About It." Oxford Review of Economic Policy 25(3): 344-67.

Flyvbjerg, B. (2014). "What You Should Know About Megaprojects and Why: An Overview." Project Management Journal 45(2): 6-19.

Mincer, J. A. and V. Zarnowitz (1969). "The Evaluation of Economic Forecasts." In J. A. Mincer, ed., Economic Forecasts and Expectations: Analyses of Forecasting Behavior and Performance. New York and London: Columbia University Press for the NBER. Pp. 1-46. http://www.nber.org/chapters/c1214

Productivity Commission (2014). Public Infrastructure Inquiry Report No. 71, Canberra. http://www.pc.gov.au/projects/inquiry/infrastructure/report 
Figure 2.1 Three-way comparison of capex, matched projects

(\$ million)

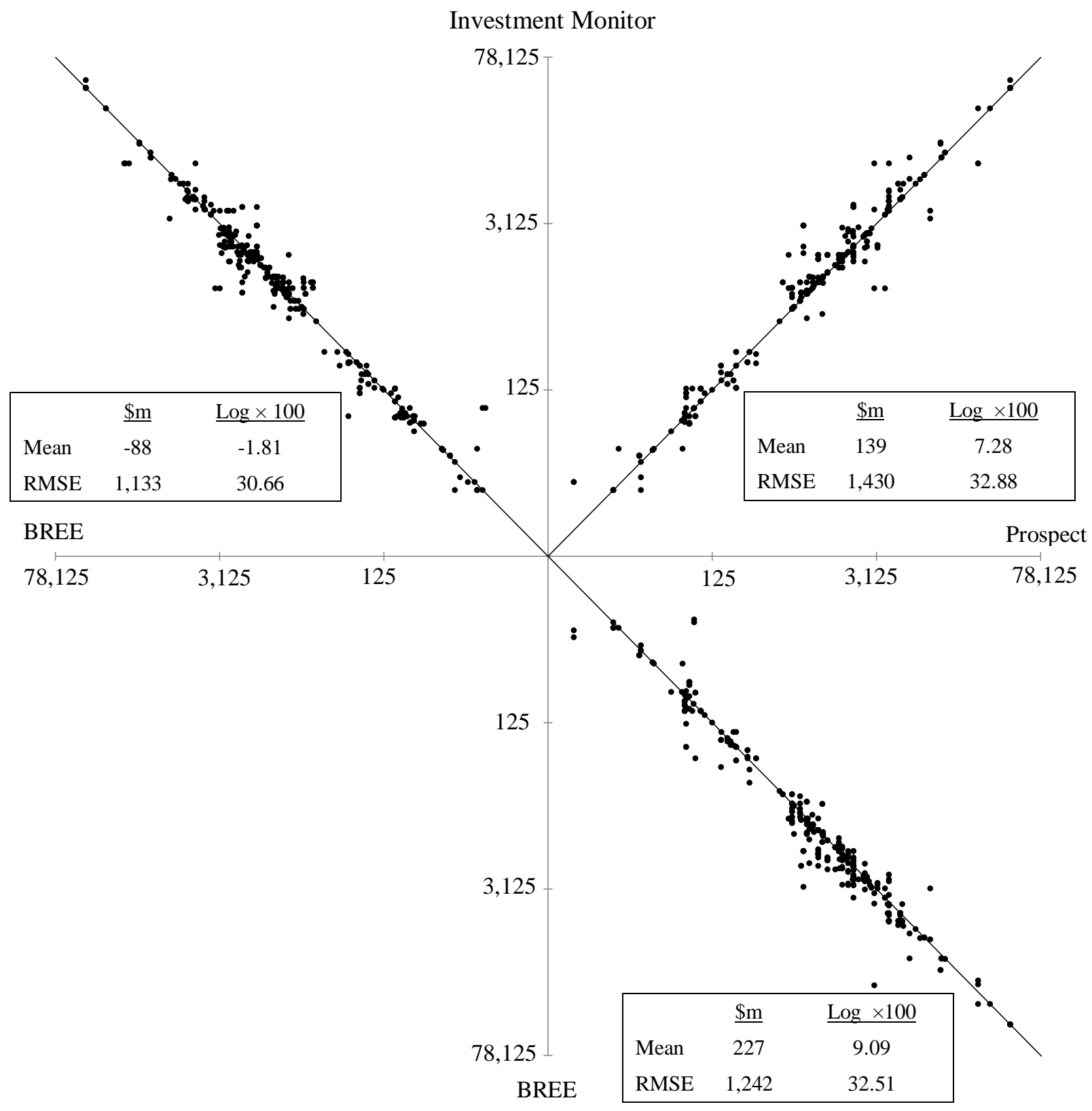

Notes:

1. The rays from the origin are 45-degree lines, along which capex from pairs of sources coincide.

2. The boxes contain the error statistics. The mean is the average difference between capex according to the source on the vertical axis minus that for the horizontal. Because the number of observations in each period is not the same in Table 2.1, the mean errors in this figure are not completely consistent with those of that table, but the differences are small. The RMSE is the root-mean-squared error. 
Figure 6.1 Capex forecast errors

(Logarithmic ratios $\times 100)$

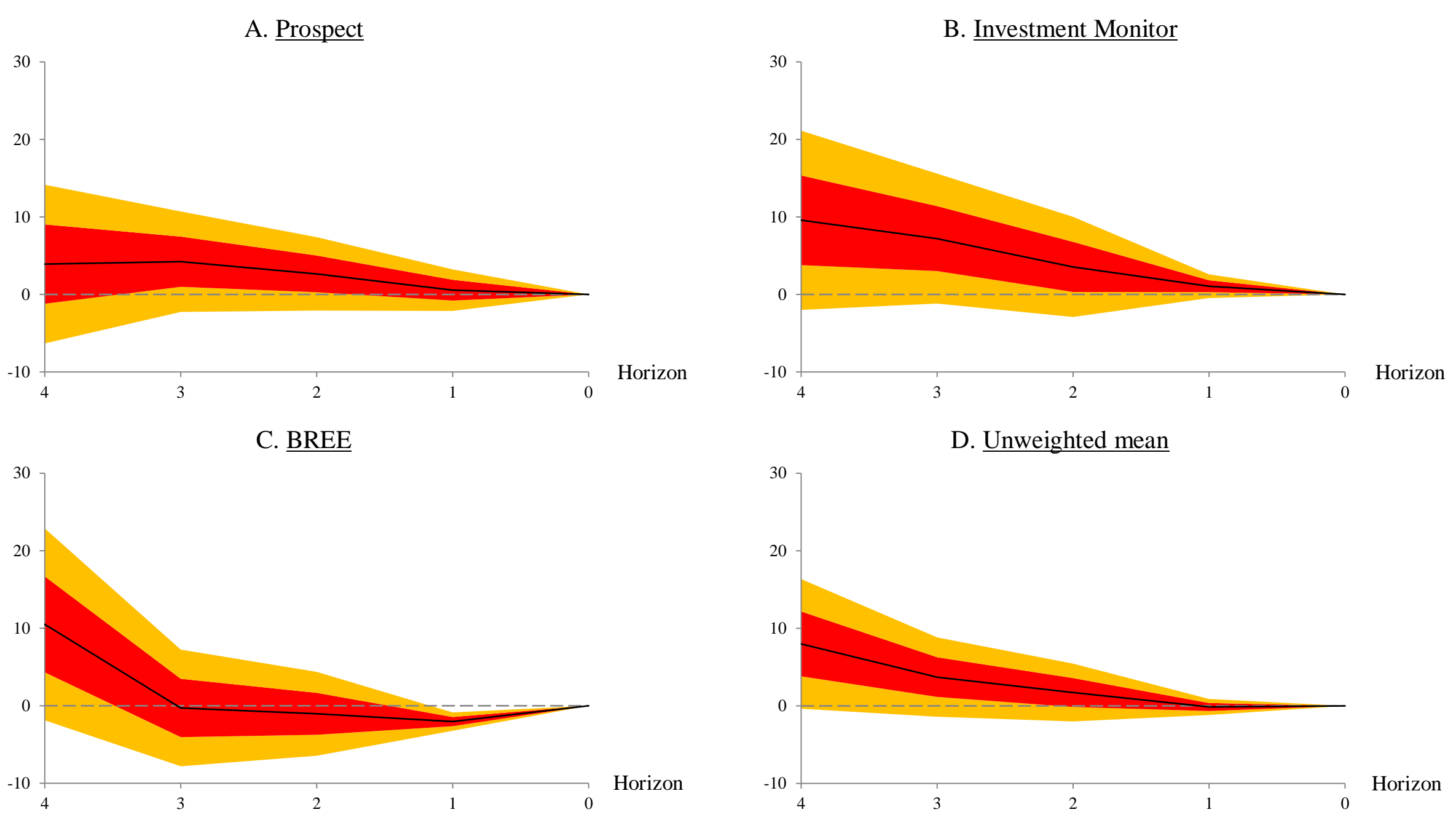

Note: The solid back line is the average forecast error; a positive value implies actual exceeds forecast. The dark and light shaded areas below and above the solid black line represent the one- and two-standard error bands, respectively. The horizon is measured in terms of six-monthly intervals. 
Table 2.1 Capex, matched projects

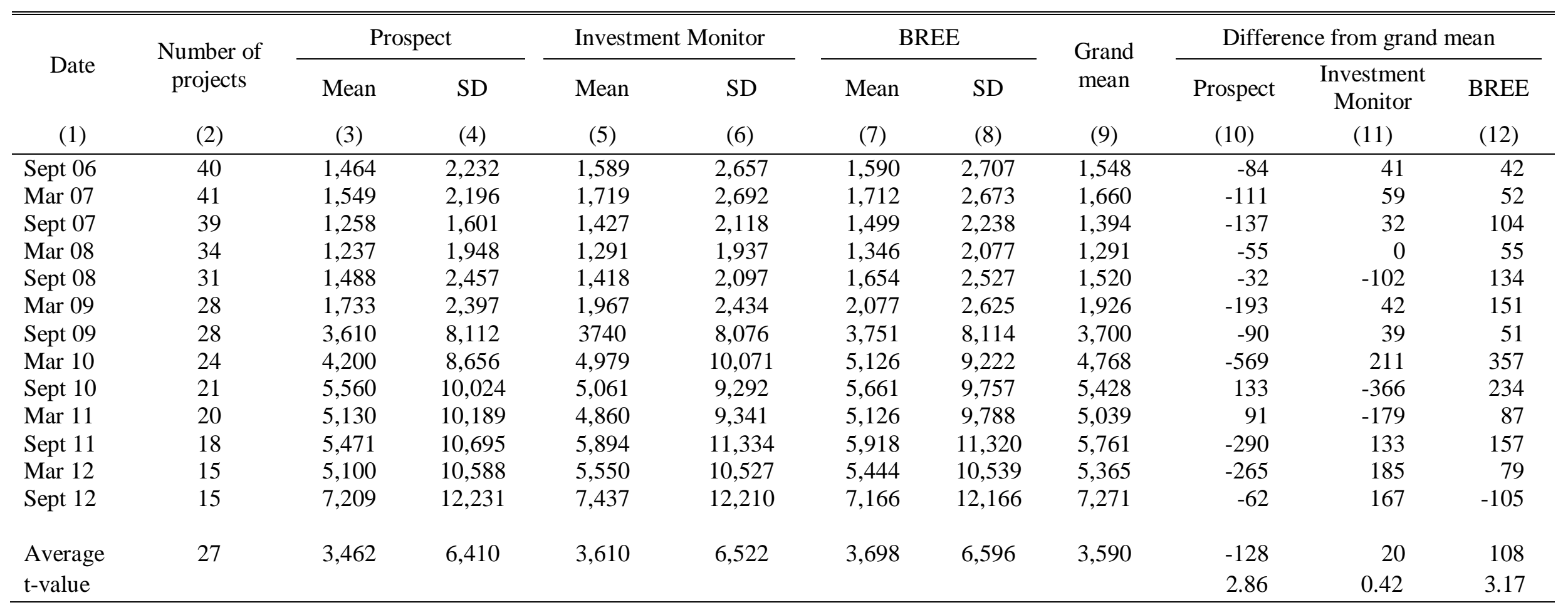

Note: Except for the first two columns and the last row, all entries are in \$Am. SD denotes standard deviation. The correlations between the sources are as follows: Prospect$\mathrm{IM}=0.977$, Prospect-BREE $=0.983$ and $\mathrm{IM}-\mathrm{BREE}=0.986$. 
Table 3.1 Hedonic costing of projects, matched projects

$$
\log v_{i t}^{s}=\gamma^{s}+\lambda_{i}+\theta_{t}+\varepsilon_{i t}^{s}
$$

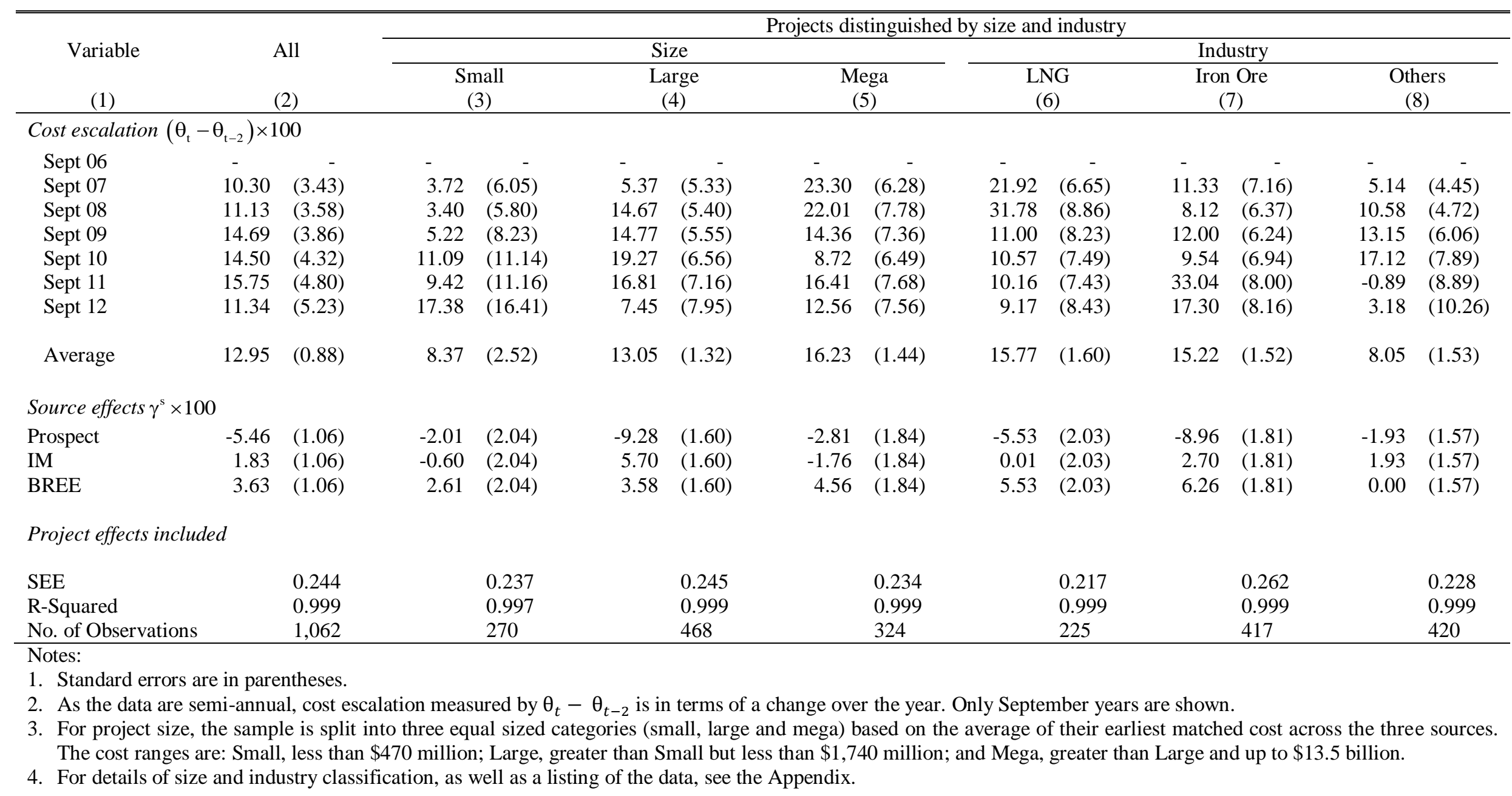


Table 4.1 Estimates of VAR model of information flows, matched projects, semi-annual, 2006-2012

$$
\mathrm{g}_{\mathrm{it}}^{\mathrm{s}}=\alpha^{\mathrm{s}}+\sum_{\mathrm{r}=1}^{3} \beta^{\mathrm{sr}} \mathrm{g}_{\mathrm{i}, \mathrm{t}-1}^{\mathrm{r}}+\text { dummies }+\varepsilon_{\mathrm{it}}^{\mathrm{s}}
$$

\begin{tabular}{|c|c|c|c|c|c|c|c|c|c|c|c|}
\hline \multirow{3}{*}{$\begin{array}{c}\text { Dependent } \\
\text { variable } \\
\mathrm{g}_{\mathrm{it}}^{\mathrm{s}} \\
(1)\end{array}$} & \multirow[b]{2}{*}{ Intercept } & \multicolumn{6}{|c|}{ Independent variables, lagged values, $\mathrm{g}_{\mathrm{i}, \mathrm{t}-1}^{\mathrm{r}}$} & \multirow[b]{2}{*}{$\mathrm{R}^{2}$} & \multirow[b]{2}{*}{ SEE } & \multicolumn{2}{|c|}{ F-tests, $H_{0}: \beta^{\text {sr }}=0$ for } \\
\hline & & \multicolumn{2}{|c|}{ Prospect } & \multicolumn{2}{|c|}{ IM } & \multicolumn{2}{|c|}{ BREE } & & & $\mathrm{r}=1,2,3$ & $\begin{array}{c}\mathrm{r}=1,2,3 \\
\mathrm{r} \neq \mathrm{s}\end{array}$ \\
\hline & (2) & \multicolumn{2}{|c|}{ (3) } & \multicolumn{2}{|c|}{$(4)$} & \multicolumn{2}{|c|}{$(5)$} & (6) & (7) & (8) & (9) \\
\hline \multicolumn{12}{|c|}{ A. Intercepts included } \\
\hline Prospect & $0.050 \quad(0.014)$ & -0.043 & $(0.057)$ & 0.017 & $(0.074)$ & 0.115 & $(0.059)$ & 0.37 & 0.198 & 1.43 & 2.07 \\
\hline IM & $0.038 \quad(0.012)$ & 0.089 & $(0.050)$ & -0.072 & $(0.065)$ & 0.101 & $(0.052)$ & 0.25 & 0.174 & 2.83 & 4.10 \\
\hline BREE & $0.041 \quad(0.017)$ & 0.056 & $(0.068)$ & 0.210 & $(0.088)$ & -0.190 & $(0.070)$ & 0.12 & 0.235 & 3.97 & 3.43 \\
\hline \multicolumn{12}{|c|}{ B. Intercepts supressed } \\
\hline Prospect & - & -0.009 & $(0.058)$ & 0.070 & $(0.075)$ & 0.145 & $(0.060)$ & 0.34 & 0.204 & 2.74 & 3.94 \\
\hline $\mathrm{IM}$ & - & 0.115 & $(0.051)$ & -0.032 & $(0.065)$ & 0.123 & $(0.052)$ & 0.22 & 0.178 & 4.46 & 6.59 \\
\hline BREE & - & 0.084 & $(0.068)$ & 0.253 & $(0.087)$ & -0.166 & $(0.070)$ & 0.10 & 0.237 & 4.54 & 5.60 \\
\hline
\end{tabular}

1. The dummies deal with transition from the last observation on one project to the first observation of the next. For details, see Clements et al. (2014).

2. Standard errors in parenthesis.

3. The model of panel A has an AIC value of -0.703; panel B AIC $=-0.635$. These are insignificantly different $(\mathrm{p}=0.97)$. 
Table 5.1 Relative information flows

\begin{tabular}{|c|c|c|c|c|}
\hline $\begin{array}{l}\text { Source } \\
\text { (1) }\end{array}$ & $\begin{array}{c}\text { Prospect } \\
\text { (2) }\end{array}$ & $\begin{array}{l}\text { IM } \\
\text { (3) }\end{array}$ & $\begin{array}{l}\text { BREE } \\
(4)\end{array}$ & $\begin{array}{l}\text { Row sum } \\
\text { (5) }\end{array}$ \\
\hline \multicolumn{5}{|c|}{ A. Coefficient matrix $\left[\hat{\beta}^{\mathrm{sr}} \times 100\right]$} \\
\hline Prospect & {$[-4.3(5.7)$} & $1.7(7.4)$ & $11.5(5.9)$ & \\
\hline IM & $8.9(5.0)$ & $-7.2(6.5)$ & $10.1(7.0)$ & \\
\hline BREE & $5.6(6.8)$ & $21.0(8.8)$ & $-19.0(7.0)$ & \\
\hline \multicolumn{5}{|c|}{ B. Transpose $\left[\hat{\beta}^{\mathrm{rs}} \times 100\right]$} \\
\hline Prospect & {$[-4.3(5.7)$} & $8.9(5.0)$ & $5.6(6.8)$ & \\
\hline IM & $1.7(7.4)$ & $-7.2(6.5)$ & $21.0(8.8)$ & \\
\hline BREE & $11.5(5.9)$ & $10.1(7.0)$ & $-19.0(7.0)$ & \\
\hline \multicolumn{5}{|c|}{ C. Net information flows $\Gamma=\left(\hat{\beta}^{\mathrm{sr}}-\hat{\beta}^{\mathrm{rs}}\right) \times 100$} \\
\hline Prospect & 0 & $-7.1(9.0)$ & $6.0(9.0)$ & $-1.1(12.2)$ \\
\hline $\mathrm{IM}$ & $7.1(9.0)$ & 0 & $-10.9(10.2)$ & $-3.8(13.3)$ \\
\hline BREE & $-6.0(9.0)$ & $10.9(10.2)$ & 0 & $4.9(13.1)$ \\
\hline Total & $1.1(12.2)$ & 3.8 (13.3) & $-4.9(13.1)$ & 0.0 \\
\hline
\end{tabular}

Notes:

1. Panel A is from Table 4.1.

2. In panel $\mathrm{C}$ the elements of the matrix refer to the bilateral information balances. A positive element indicates that the row source receives more information from the column source than it sends in return; vice versa for a negative element. The row sums refer to the multilateral balances. A positive row sum indicates the source receives more information from the others than it sends in return; vice versa for a negative row sum.

3. Standard errors in parentheses. 
Table 6.1 Combining forecasts of capex costs $\log \mathrm{v}_{\mathrm{i}, \mathrm{T}_{\mathrm{i}}}=\beta_{0}+\sum_{\mathrm{s}=1}^{3} \beta_{1}^{\mathrm{s}} \log \mathrm{v}_{\mathrm{i}, \mathrm{T}_{\mathrm{i}}-\mathrm{h}}^{\mathrm{s}}+\varepsilon_{\mathrm{i}}, \quad \mathrm{i}=1, \ldots, \mathrm{N}_{\mathrm{h}}$

\begin{tabular}{|c|c|c|c|c|c|c|c|c|c|c|}
\hline \multirow{2}{*}{$\begin{array}{l}\text { Forecast } \\
\text { horizon } \\
\text { (6-month } \\
\text { periods) }\end{array}$} & \multirow{2}{*}{$\begin{array}{c}\text { Intercept } \\
\beta_{0}\end{array}$} & \multicolumn{3}{|c|}{$\beta_{1}^{\mathrm{s}}$, coefficients of forecast from } & \multirow{2}{*}{$\begin{array}{l}\text { Sum } \\
\sum_{\mathrm{s}=1}^{3} \beta_{1}^{\mathrm{s}}\end{array}$} & \multirow{2}{*}{$\begin{array}{l}\text { SEE } \\
\times 100\end{array}$} & \multirow{2}{*}{$\mathrm{R}^{2}$} & \multirow{2}{*}{$\begin{array}{l}\text { Number of } \\
\text { projects }\end{array}$} & \multicolumn{2}{|c|}{$\begin{array}{l}\text { Equal coefficients, } \beta_{1}^{s}=\beta_{1} \\
\qquad s=1,2,3\end{array}$} \\
\hline & & Prospect & $\mathrm{IM}$ & BREE & & & & & Probability & $\begin{array}{l}\text { Restricted } \\
\text { estimate } \beta\end{array}$ \\
\hline 4 & $0.657(0.535)$ & $0.494(0.443)$ & $0.815(0.783)$ & $-0.385(0.792)$ & $0.924(0.072)$ & 17.15 & 0.959 & 14 & 0.681 & $0.314(0.019)$ \\
\hline 3 & $0.116(0.225)$ & $0.113(0.191)$ & $0.286(0.191)$ & $0.587(0.263)$ & $0.986(0.030)$ & 12.08 & 0.986 & 20 & 0.524 & $0.326(0.010)$ \\
\hline
\end{tabular}

Notes: Standard errors are in parentheses. SEE is the standard error of estimate. Column 10 contains p-values for F-statistics of $\mathrm{H}_{0}: \beta_{1}^{\mathrm{s}}=\beta_{1}, \mathrm{~s}=1,2,3$.

Table 6.2 The accuracy of capex forecasts

\begin{tabular}{|c|c|c|c|c|c|c|c|c|c|c|c|c|c|}
\hline \multirow{3}{*}{$\begin{array}{l}\text { Forecast } \\
\text { horizon } \\
\text { (6-month } \\
\text { periods) }\end{array}$} & \multicolumn{12}{|c|}{ Forecast errors (Logarithmic ratios $\times 100$ ) } & \multirow{3}{*}{$\begin{array}{c}\text { Number of } \\
\text { projects } \\
\text { (14) }\end{array}$} \\
\hline & \multicolumn{3}{|c|}{ Prospect } & \multicolumn{3}{|c|}{ IM } & \multicolumn{3}{|c|}{ BREE } & \multicolumn{3}{|c|}{ Unweighted mean } & \\
\hline & Mean & SD & RMSE & Mean & SD & RMSE & Mean & $\mathrm{SD}$ & RMSE & Mean & SD & RMSE & \\
\hline 4 & 3.91 & 19.15 & 19.54 & 9.56 & 21.62 & 23.64 & 10.50 & 23.15 & 25.42 & 7.99 & 15.64 & 17.56 & 14 \\
\hline 3 & 4.22 & 14.48 & 15.09 & 7.20 & 18.74 & 20.08 & -0.28 & 16.82 & 16.82 & 3.71 & 11.43 & 12.02 & 20 \\
\hline 2 & 2.65 & 12.07 & 12.36 & 3.55 & 16.47 & 16.85 & -1.04 & 13.79 & 13.83 & 1.72 & 9.50 & 9.66 & 26 \\
\hline
\end{tabular}


Table 7.1 Summary comparison of three sources of capex data

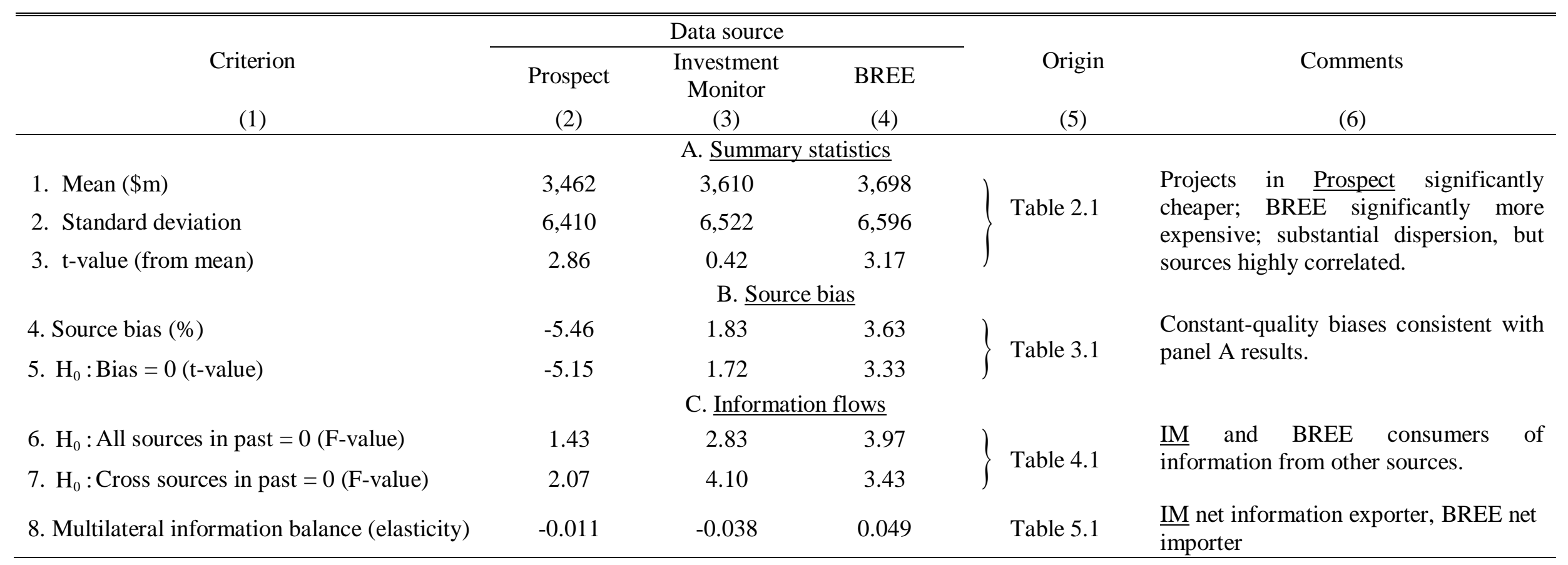




\section{Appendix to \\ UNDERSTANDING NEW RESOURCE PROJECTS}

The appendix presents the underlying data and some additional results as well as elaborating further some of the findings in the text of the paper.

\section{A1. The Data}

The data come from three sources, Prospect, $\underline{\mathrm{IM}}$ and BREE, and projects included in this data set appear in each of the three sources. Projects were individually matched by hand and the Microsoft Excel "Fuzzy Lookup" plugin used as a cross check. The matching process was time consuming as it involved, for example, identifying cases in which the same project was referred to by different names and the use of the same project number to refer to different projects. The sample period starts in March 2006 and finishes in September 2012. These data are semiannual, so there are 13 time-wise observations. The 354 matched triplets $(3 \times 354=$ 1,062 observations in total) are listed in Table A1.1, along with cost and industry identifiers used in the hedonics in Section 3. For full details of the data, refer to Clements et al. (2014).

As discussed in Clements et al. (2014), there are slight asynchronies in the dates of the publication of the three sources. The March (September) issues of $\underline{\mathrm{IM}}$ and $\underline{\text { Prospect }}$ are matched with April (October) issues of BREE. Accordingly, the data from BREE are more up-to-date by one month, relative to the other two sources. In the context of the VAR model, in essence this means that current capex growth for $\underline{\mathrm{IM}}$ is related to the BREE lagged value that is only five months before, not six. This lag is seven months when the current value for BREE is related to the previous values of $\underline{\mathrm{IM}}$ and Prospect. Thus, BREE has more time to "learn" from the publication of data from $\underline{\mathrm{IM}}$ (seven months) than $\underline{\mathrm{IM}}$ has regarding BREE (five months). This timing asymmetry may in part explain the result of Table 4.1 that BREE appears to be more influenced by $\underline{\mathrm{IM}}$ than vice versa (that is, $\hat{\beta}^{32}>\hat{\beta}^{23}$ ).

\section{A2. The Transmission of New Information}

Section 4 used a VAR approach to model the transmission of information across the three sources. To analyse the dynamic response of the system to the receipt of new information, we now consider the associated impulse response functions (IRFs). Column 3 of Table A2.1 gives the results for a shock to each variable equal to one standard error of estimate for the corresponding equation. ${ }^{11}$ By construction, the own-effects in period one are

\footnotetext{
${ }^{11}$ We consider the IRFs for two periods only (that is, one year), as they are effectively zero thereafter.
} 
equal to the shock, while the period-one cross-effects are zero as it takes at least six months for any information transmission to take place. The two-period own-effects for Prospect and $\underline{\mathrm{IM}}$ are small and insignificant, but this effect is larger and significant for BREE; these effects reflect the relative size of the estimated own-lag coefficients $\hat{\beta}^{\text {ss }}$ and the SEEs of Table 4.1.

Next, consider the cross-effects in column 3 of Table A2.1 for period two. Two values here are at least twice the corresponding standard errors:

$$
\underline{\mathrm{IM}} \text { to } \mathrm{BREE}=0.024(0.012) \quad \text { BREE to } \underline{\mathrm{IM}}=0.037(0.015) \text {, }
$$

where the figures in parentheses are standard errors. Thus, we now see that BREE provides more information to $\underline{\mathrm{IM}}$ than it receives in return. This is opposite to the result discussed above based on the direct, one-period effects as measured by the $\Gamma$ matrix. This apparent contradiction can be explained as follows. The discussion in Sections 4 and 5 dealt with the proportion of information that flows from one source to another. Thus, as $\hat{\beta}^{32}>\hat{\beta}^{23}$, a tenpercent inflation shock in $\underline{\mathrm{IM}}$ contributes more to BREE than a similar shock in BREE contributes to IM. But according to the SEEs in column 7 of panel A of Table 4.1, the BREE data contain a greater amount of unexplained variation, relative to the others. As the shock for each source that underlies the IRFs of column 3 of Table A2.1 is just this SEE, the shock for BREE is larger than that for the other two sources, which explains the above result. In other words, BREE incorporates a greater proportion of a given innovation from $\underline{\mathrm{IM}}$ than vice versa, but BREE also contributes more innovations than IM.

The above IRFs trace out the trajectory of cost inflation following a given shock to the residual of one equation. The results, however, cannot be completely ascribed to an independent shock to the equation in question as the residuals are correlated across equations. The issue can be dealt with by the Cholesky orthogonalisation of the residuals. We use the ordering of variables: $\underline{\text { Prospect }}>\underline{\mathrm{IM}}>\mathrm{BREE}$. BREE is last in the ordering due to its onemonth publication lag mentioned in Section 4 (and discussed in more detail in Clements et al., 2014). Similarly, as Prospect tends to publish slightly ahead of $\underline{\mathrm{IM}}$ (see Clements et al., 2014, for details), Prospect is ordered first. Column 4 of Table A2.1 gives the IRFs associated with the Cholesky factorisation. For the own-effects, these results are quite similar to those of column 3. The cross-effects are also similar, except now three period-one effects are relatively large:

$\underline{\text { IM to Prospect }} 0.026(0.010)$, BREE to Prospect 0.064 (0.014), BREE to IM $0.041(0.013)$. 
Thus, BREE is now quite sensitive to the other two sources: Following a one-standarddeviation shock of the transformed residuals of Prospect, after a six-month lag, inflation, as measured by BREE, increases by about six percent, while it increases by four percent following a similar shock from IM. This result, which is different from before (when these effects were all zero), highlights the role of new information that is common to the three sources. This information hits all sources simultaneously in the form of correlated shocks. ${ }^{12}$

An error correction model is an alternative approach to analysing the speed at which information travels to each source dynamics. If the three sources of capex $\left(\log v_{i t}^{r}, r=1,2,3\right)$ are cointegrated, then the linear combination $\mu+\Sigma_{r=1}^{3} \beta^{r} \log v_{i, t-1}^{r}$ is stationary and can be treated as a deviation from equilibrium that is common for each source in a VEC model:

$$
\mathrm{g}_{\mathrm{it}}^{\mathrm{s}}=\alpha^{\mathrm{s}}\left(\mu+\sum_{\mathrm{r}=1}^{3} \beta^{\mathrm{r}} \log \mathrm{v}_{\mathrm{i}, \mathrm{t}-1}^{\mathrm{r}}\right)+\mathrm{c}^{\mathrm{s}}+\sum_{\mathrm{r}=1}^{3} \gamma^{\mathrm{sr}} \mathrm{g}_{\mathrm{i}, \mathrm{t}-1}^{\mathrm{r}}+\varepsilon_{\mathrm{it}}^{\mathrm{s}}, \quad \mathrm{s}=1,2,3,
$$

where, for source $s, \alpha^{s}$ is the speed of adjustment, $c^{s}$ is an intercept, $\varepsilon_{i t}^{s}$ is a disturbance and the $\gamma^{\text {sr }}$ 's are parameters that deal with any autocorrelation. The adjustment coefficients are the key parameters for our purpose and their estimates with the matched data are

$$
\text { Prospect }-0.074(0.031), \quad \underline{I M}-0.138(0.027), \quad \text { BREE } 0.138(0.035) \text {, }
$$

where standard errors are in parentheses. Thus, IM and BREE revise their data at about the same speed, while Prospect is much slower. For further details, see Clements et al. (2014).

\section{A3. Sources' Resources}

Another way of assessing the quality of the three data sources might be to compare the resources devoted to each -- the more resources, the better the product. The problem is that resource inputs are not directly observable. But it may be possible to measure this indirectly by the number of instances in which the capex costs are changed, on the basis that more changes may reflect greater collection of more new information, more recording activity and/or more resources devoted to maintaining and updating the database. In this

\footnotetext{
${ }^{12}$ The second-period lags of the column 4 IRFs accord more closely with those of column 3. Three further sensitivities of the results can also be noted. (i) When the VAR intercepts are supressed, the corresponding IRFs are in columns 5 and 6 of Table A2.1. In general, these are similar to those with the intercepts included. (ii) We also experimented with second- and fourth-order VARs, but the results, in terms of the value of the AIC, are no better. This is not unexpected as it is unlikely that information should take longer than six months to move directly between sources. (iii) Interchanging Prospect and IM in the Cholesky ordering has little effect on the results. See Clements et al. (2014) for details.
} 
section we investigate this issue by examining the extent to which old and outdated capex projections remain on the books.

Figure A3.1 depicts the incidence of capex updates. Of the 282 triplets, in 92 cases there is no change in any source. These cases are represented by that part of the rectangle that lies outside the three circles. The area of each circle is proportional to the number of cases when the data in the respective source are revised. The tendency for BREE to update more frequently is immediately apparent. Moreover, as indicated by the "non-overlapping" area in its circle, BREE has more than twice as many unique revisions as do the other sources combined (84 vs. $11+26=37)$.

Do we know that more frequently revised data are of higher quality? Rather than additional information, could updates simply add more noise, so there might be a distinction between the nominal and effective quality? While iron-clad guarantees of quality cannot be provided, two points can be made in this regard. First, suppose one source were producing "information" of dubious value. Presumably, this would be apparent to the other two, who would tend not to place reliance on the "noise producer". But as indicated in Sections 4 and 5 , there are substantial two-way flows of information across sources over time, which points to valuable information.

The second point relates to the coincidence of revisions. In Table A3.1 we test the hypothesis that revisions of each source are independent of that of their counterparts. The large $\chi^{2}$-statistics for BREE and Prospect mean that independence is rejected, so that these are dependent on the other sources. By contrast, the small $\chi^{2}$-value for IM indicates it revises more independently of the other two sources. This can be interpreted as saying the revisions to $\underline{\mathrm{IM}}$ are less redundant, or more unique, than those of the other two sources, even though BREE revises more frequently. ${ }^{13}$

\section{$\underline{\text { Reference }}$}

Clements, K. W. and J. Si and T. Simpson (2014). "Understanding New Resource Projects." Economics Discussion Paper 14.17, UWA Business School. http://www.business.uwa.edu.au/_data/assets/pdf_file/0005/2530058/14.17Understanding-New-Resource-Projects.pdf

\footnotetext{
${ }^{13}$ As discussed in Clements et al. (2014), there are a modest number of missing observations for which zero cost escalation is assumed. As most of these pertain to BREE, this would bias the revision frequency count and the contingency-table test of independence in favour of $\underline{\mathrm{IM}}$ and Prospect. We judge this to be of minor importance, however.
} 
Figure A3.1 Revision frequency (282 triplets)

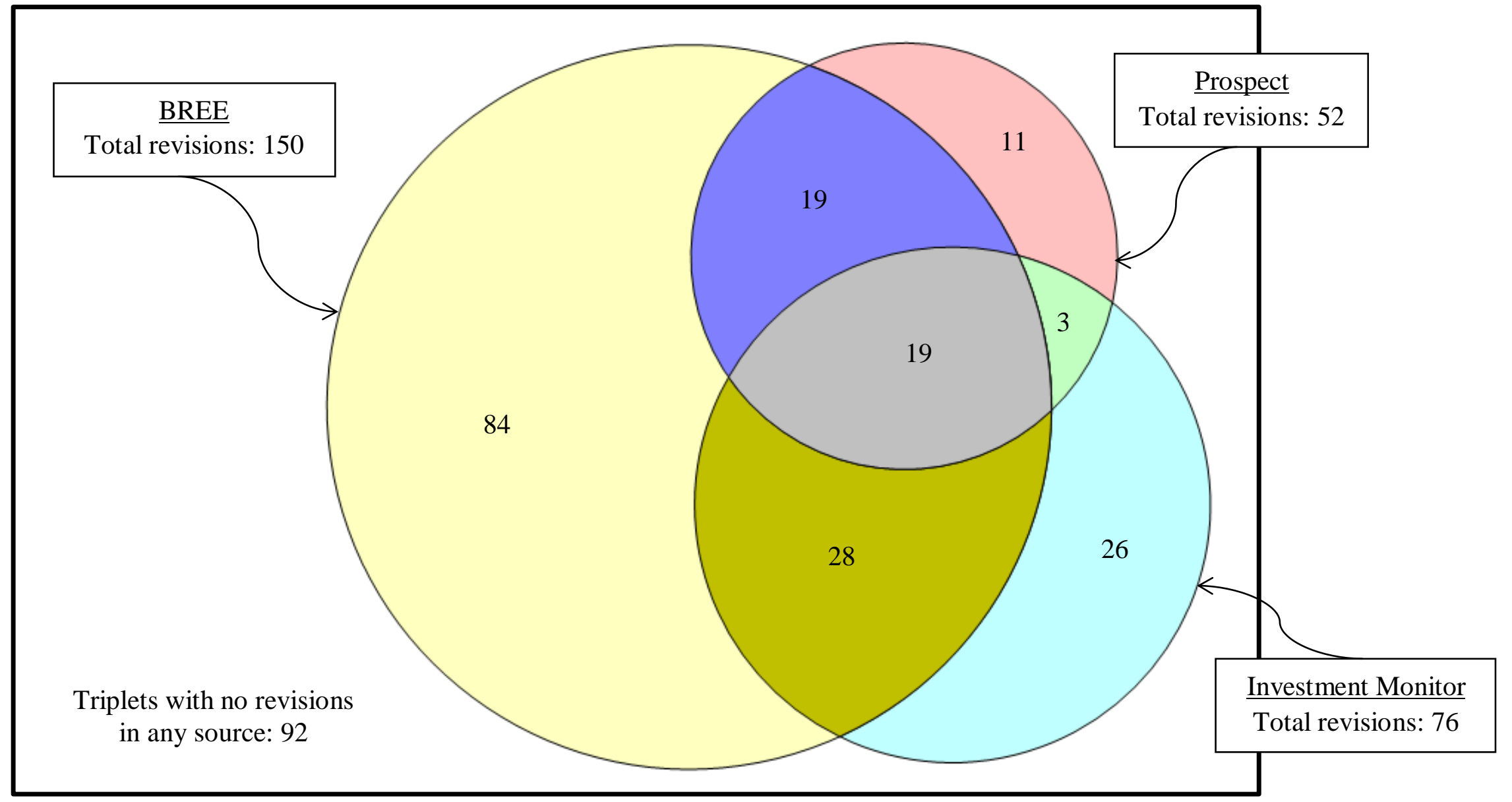


Table A1.1 Matched triplets of projects, by project size

\begin{tabular}{|c|c|c|c|c|c|c|}
\hline \multirow{2}{*}{$\begin{array}{l}\text { Row } \\
\text { no. } \\
(1)\end{array}$} & \multirow{2}{*}{$\begin{array}{c}\text { Year/ } \\
\text { Quarter } \\
(2)\end{array}$} & \multirow[b]{2}{*}{$\begin{array}{c}\text { Project } \\
\text { (3) }\end{array}$} & \multirow[b]{2}{*}{$\begin{array}{c}\text { Industry } \\
\text { (4) }\end{array}$} & \multicolumn{3}{|c|}{ Cost $(\$ m)$} \\
\hline & & & & $\begin{array}{l}\mathrm{PR} \\
(5)\end{array}$ & $\begin{array}{l}\text { IM } \\
(6)\end{array}$ & $\begin{array}{l}\text { BR } \\
(7)\end{array}$ \\
\hline \multicolumn{7}{|c|}{ A. Small } \\
\hline 1. & 2006 Q3 & Halls Creek — Panton Sill — Platinum Project & Other & 80 & 65 & 61 \\
\hline 2. & 2007 Q1 & Halls Creek — Panton Sill — Platinum Project & Other & 80 & 65 & 61 \\
\hline 3. & 2007 Q3 & Halls Creek - Panton Sill - Platinum Project & Other & 80 & 65 & 57 \\
\hline 4. & 2008 Q1 & Halls Creek - Panton Sill — Platinum Project & Other & 80 & 65 & 57 \\
\hline 5. & $2008 \mathrm{Q} 3$ & Halls Creek - Panton Sill — Platinum Project & Other & 80 & 65 & 57 \\
\hline 6. & 2006 Q3 & Jangardup South - Mineral Sands Mine & Other & 40 & 40 & 40 \\
\hline 7. & 2007 Q1 & Jangardup South - Mineral Sands Mine & Other & 70 & 40 & 40 \\
\hline 8. & 2007 Q3 & Kemerton - Titanium Dioxide Pigment Plant Expansion & Other & 470 & 470 & 470 \\
\hline 9. & 2008 Q3 & Kwinana - Titanium Dioxide Pigment Plant Expansion & Other & 100 & 100 & 100 \\
\hline 10. & 2009 Q1 & Kwinana - Titanium Dioxide Pigment Plant Expansion & Other & 100 & 100 & 100 \\
\hline 11. & 2009 Q3 & Kwinana - Titanium Dioxide Pigment Plant Expansion & Other & 100 & 100 & 100 \\
\hline 12. & 2006 Q3 & Mt Weld - Rare Earths Operations & Other & 80 & 66 & 75 \\
\hline 13. & 2007 Q1 & Mt Weld - Rare Earths Operations & Other & 80 & 75 & 96 \\
\hline 14. & 2007 Q3 & Mt Weld - Rare Earths Operations & Other & 90 & 75 & 250 \\
\hline 15. & 2008 Q1 & Mt Weld - Rare Earths Operations & Other & 90 & 75 & 70 \\
\hline 16. & 2008 Q3 & Mt Weld - Rare Earths Operations & Other & 90 & 75 & 70 \\
\hline 17. & 2006 Q3 & Sunrise Dam - Gold Mine - Underground Development & Other & 87 & 87 & 87 \\
\hline 18. & 2006 Q3 & North Eastern Gold?elds - Jaguar - Base Metals Mine & Other & 56 & 56 & 69 \\
\hline 19. & 2007 Q1 & North Eastern Gold?elds - Jaguar - Base Metals Mine & Other & 69 & 69 & 69 \\
\hline 20. & 2006 Q3 & Kimberley - Koolan Island Western Australia- Iron Ore Mine & Iron Ore & 125 & 125 & 125 \\
\hline 21. & 2006 Q3 & Exmouth - Exmouth Solar Salt Project & Other & 200 & 130 & 200 \\
\hline 22. & 2007 Q3 & Exmouth - Exmouth Solar Salt Project & Other & 200 & 130 & 150 \\
\hline 23. & 2008 Q1 & Exmouth - Exmouth Solar Salt Project & Other & 200 & 130 & 200 \\
\hline 24. & 2008 Q3 & Exmouth - Exmouth Solar Salt Project & Other & 200 & 130 & 200 \\
\hline 25. & 2009 Q1 & Exmouth - Exmouth Solar Salt Project & Other & 200 & 200 & 200 \\
\hline 26. & 2009 Q3 & Exmouth - Exmouth Solar Salt Project & Other & 200 & 200 & 200 \\
\hline 27. & 2006 Q3 & Pilbara - Nickel Mine & Other & 30 & 35 & 34 \\
\hline 28. & 2007 Q1 & Pilbara - Nickel Mine & Other & 30 & 35 & 34 \\
\hline 29. & 2007 Q3 & Pilbara - Nickel Mine & Other & 30 & 35 & 34 \\
\hline 30. & 2008 Q1 & Pilbara - Nickel Mine & Other & 30 & 35 & 34 \\
\hline 31. & 2008 Q3 & Pilbara - Nickel Mine & Other & 30 & 35 & 34 \\
\hline 32. & 2006 Q3 & Shark Bay / Coburn - Heavy Mineral Sands Mine & Other & 75 & 128 & 128 \\
\hline 33. & 2007 Q1 & Shark Bay / Coburn - Heavy Mineral Sands Mine & Other & 85 & 128 & 100 \\
\hline 34. & 2007 Q3 & Shark Bay / Coburn - Heavy Mineral Sands Mine & Other & 100 & 128 & 100 \\
\hline 35. & 2008 Q1 & Shark Bay / Coburn - Heavy Mineral Sands Mine & Other & 100 & 128 & 100 \\
\hline 36. & 2008 Q3 & Shark Bay / Coburn - Heavy Mineral Sands Mine & Other & 100 & 128 & 100 \\
\hline 37. & 2009 Q1 & Shark Bay / Coburn - Heavy Mineral Sands Mine & Other & 100 & 128 & 100 \\
\hline 38. & 2009 Q3 & Shark Bay / Coburn - Heavy Mineral Sands Mine & Other & 100 & 128 & 100 \\
\hline 39. & 2010 Q1 & Shark Bay / Coburn - Heavy Mineral Sands Mine & Other & 169 & 140 & 169 \\
\hline 40. & 2010 Q3 & Shark Bay / Coburn - Heavy Mineral Sands Mine & Other & 169 & 140 & 169 \\
\hline 41. & 2011 Q1 & Shark Bay / Coburn - Heavy Mineral Sands Mine & Other & 169 & 169 & 169 \\
\hline 42. & $2011 \mathrm{Q} 3$ & Shark Bay / Coburn - Heavy Mineral Sands Mine & Other & 169 & 169 & 180 \\
\hline 43. & 2012 Q1 & Shark Bay / Coburn - Heavy Mineral Sands Mine & Other & 180 & 169 & 180 \\
\hline 44. & 2012 Q3 & Shark Bay / Coburn - Heavy Mineral Sands Mine & Other & 180 & 169 & 193 \\
\hline 45. & 2006 Q3 & North Eastern Gold?elds - Yakabindie - Nickel Mine & Other & 20 & 40 & 20 \\
\hline 46. & 2006 Q3 & Kwinana - Ammonium Nitrate Plant \& Expansions & Other & 200 & 260 & 260 \\
\hline 47. & 2007 Q1 & Kwinana - Ammonium Nitrate Plant \& Expansions & Other & 200 & 260 & 260 \\
\hline 48. & 2007 Q3 & Kwinana - Ammonium Nitrate Plant \& Expansions & Other & 260 & 260 & 310 \\
\hline 49. & 2008 Q1 & Kwinana - Ammonium Nitrate Plant \& Expansions & Other & 260 & 260 & 400 \\
\hline 50. & 2006 Q3 & Keysbrook - Heavy Mineral Sands Mine & Other & 31 & 31 & 31 \\
\hline 51. & 2007 Q1 & Keysbrook - Heavy Mineral Sands Mine & Other & 31 & 18 & 31 \\
\hline 52. & 2007 Q3 & Keysbrook - Heavy Mineral Sands Mine & Other & 18 & 18 & 18 \\
\hline 53. & 2008 Q1 & Keysbrook - Heavy Mineral Sands Mine & Other & 18 & 18 & 20 \\
\hline 54. & 2008 Q3 & Keysbrook - Heavy Mineral Sands Mine & Other & 18 & 18 & 20 \\
\hline 55. & 2009 Q1 & Keysbrook - Heavy Mineral Sands Mine & Other & 18 & 18 & 20 \\
\hline 56. & 2006 Q3 & Windimurra - Vanadium Pentoxide mine and processing plant & Other & 149 & 175 & 175 \\
\hline 57. & 2007 Q1 & Windimurra - Vanadium Pentoxide mine and processing plant & Other & 149 & 200 & 175 \\
\hline 58. & 2007 Q3 & Windimurra - Vanadium Pentoxide mine and processing plant & Other & 149 & 200 & 296 \\
\hline 59. & 2008 Q1 & Windimurra - Vanadium Pentoxide mine and processing plant & Other & 296 & 209 & 250 \\
\hline 60. & $2008 \mathrm{Q} 3$ & Windimurra - Vanadium Pentoxide mine and processing plant & Other & 296 & 250 & 250 \\
\hline 61. & 2007 Q1 & Midwest Region - Karara Hematite Project & Iron Ore & 75 & 88 & 75 \\
\hline 62. & 2007 Q3 & Midwest Region - Karara Hematite Project & Iron Ore & 75 & 108 & 94 \\
\hline 63. & 2008 Q1 & Mid West Region - Mungada Hematite Mine & Iron Ore & 75 & 117 & 200 \\
\hline 64. & 2008 Q3 & Mid West Region - Mungada Hematite Mine & Iron Ore & 75 & 117 & 200 \\
\hline 65. & 2009 Q1 & Mid West Region - Mungada Hematite Mine & Iron Ore & 108 & 117 & 108 \\
\hline 66. & 2006 Q3 & Waroona - Heavy Mineral Sands Mine & Other & 39 & 39 & 39 \\
\hline 67. & 2007 Q1 & Waroona - Heavy Mineral Sands Mine & Other & 39 & 39 & 39 \\
\hline 68. & 2006 Q3 & Lennard Shelf (Pillara) - (Plant Expansion) Zinc/Lead Mine & Other & 31 & 23 & 28 \\
\hline 69. & 2007 Q1 & Gwindinup - Heavy Mineral Sands Mine & Other & 88 & 88 & 18 \\
\hline 70. & 2007 Q3 & Gwindinup - Heavy Mineral Sands Mine & Other & 88 & 88 & 17 \\
\hline 71. & 2007 Q1 & Mid West Region - Extension Hill Hematite Mine & Iron Ore & 73 & 67 & 73 \\
\hline 72. & $2007 \mathrm{Q} 3$ & Mid West Region - Extension Hill Hematite Mine & Iron Ore & 73 & 73 & 84 \\
\hline
\end{tabular}


Table A1.1 Matched triplets of projects, by project size (continued)

\begin{tabular}{|c|c|c|c|c|c|c|}
\hline \multirow{3}{*}{$\begin{array}{c}\text { Row } \\
\text { no. } \\
(1) \\
\end{array}$} & \multirow{3}{*}{$\begin{array}{c}\text { Year/ } \\
\text { Quarter } \\
(2)\end{array}$} & \multirow{3}{*}{$\begin{array}{c}\text { Project } \\
\text { (3) }\end{array}$} & \multirow{3}{*}{$\begin{array}{c}\text { Industry } \\
\text { (4) }\end{array}$} & \multicolumn{3}{|c|}{ Cost $(\$ m)$} \\
\hline & & & & PR & IM & BR \\
\hline & & & & $(5)$ & $(6)$ & (7) \\
\hline 73. & $2008 \mathrm{Q} 1$ & Mid West Region - Extension Hill Hematite Mine & Iron Ore & 73 & 73 & 100 \\
\hline 74. & 2008 Q3 & Mid West Region - Extension Hill Hematite Mine & Iron Ore & 73 & 73 & 100 \\
\hline 75. & 2009 Q1 & Mid West Region - Extension Hill Hematite Mine & Iron Ore & 73 & 73 & 100 \\
\hline 76. & 2009 Q3 & Mid West Region - Extension Hill Hematite Mine & Iron Ore & 73 & 73 & 100 \\
\hline 77. & $2010 \mathrm{Q} 3$ & Mid West Region - Extension Hill Hematite Mine & Iron Ore & 73 & 73 & 89 \\
\hline 78. & $2011 \mathrm{Q} 1$ & Mid West Region - Extension Hill Hematite Mine & Iron Ore & 73 & 80 & 82 \\
\hline 79. & $2011 \mathrm{Q} 3$ & Mid West Region - Extension Hill Hematite Mine & Iron Ore & 73 & 80 & 90 \\
\hline 80. & 2007 Q3 & Pilbara - Pardoo Hematite DSO Mine & Iron Ore & 8 & 21 & 21 \\
\hline 81. & 2008 Q1 & Pilbara - Pardoo Hematite DSO Mine & Iron Ore & 8 & 21 & 24 \\
\hline 82. & 2007 Q3 & Pilbara - Panorama Copper/Zinc mine & Other & 250 & 213 & 213 \\
\hline 83. & 2008 Q1 & Pilbara - Panorama Copper/Zinc mine & Other & 250 & 213 & 213 \\
\hline 84. & $2008 \mathrm{Q} 3$ & Pilbara - Panorama Copper/Zinc mine & Other & 250 & 213 & 242 \\
\hline 85. & 2009 Q3 & Ravensthorpe - Mt Cattlin Tantalum and Lithium Mine & Other & 75 & 75 & 68 \\
\hline 86. & 2010 Q1 & Great Southern Region - Mount Cattlin Lithium Project, Ravensthorpe & Other & 75 & 75 & 79 \\
\hline 87. & $2010 \mathrm{Q} 3$ & Ravensthrpe - Ravensthrope Nickel Operation & Other & 150 & 150 & 150 \\
\hline 88. & $2011 \mathrm{Q} 1$ & Ravensthrpe - Ravensthrope Nickel Operation & Other & 190 & 150 & 150 \\
\hline 89. & $2011 \mathrm{Q} 3$ & Ravensthrpe - Ravensthrope Nickel Operation & Other & 190 & 150 & 194 \\
\hline 90. & $2012 \mathrm{Q} 3$ & Mt Windarra - Windarra Nickel & Other & 250 & 213 & 250 \\
\hline \multicolumn{7}{|c|}{ B. Large } \\
\hline 91. & 2006 Q3 & Wagerup/Willowdale - Alumina Refinery/Bauxite Mine Expansion Train 3 & Other & 1,500 & 1,700 & 1,500 \\
\hline 92. & 2007 Q1 & Wagerup/Willowdale - Alumina Refinery/Bauxite Mine Expansion Train 3 & Other & 1,500 & 1,700 & 1,500 \\
\hline 93. & 2007 Q3 & Wagerup/Willowdale - Alumina Refinery/Bauxite Mine Expansion Train 3 & Other & 1,500 & 1,700 & 1,500 \\
\hline 94. & 2008 Q1 & Wagerup/Willowdale - Alumina Refinery/Bauxite Mine Expansion Train 3 & Other & 1,500 & 1,700 & 1,500 \\
\hline 95. & 2006 Q3 & Hope Downs — Iron Ore Mine & Iron Ore & 1,500 & 1,330 & 1,310 \\
\hline 96. & 2007 Q1 & Hope Downs - Iron Ore Mine & Iron Ore & 1,500 & 1,330 & 1,270 \\
\hline 97. & 2007 Q3 & Hope Downs - Iron Ore Mine & Iron Ore & 1,500 & 1,330 & 1,170 \\
\hline 98. & 2010 Q3 & Carnarvon Offshore Basin - Macedon - Gas Field & LNG & 1,000 & 1,570 & 1,700 \\
\hline 99. & $2011 \mathrm{Q} 1$ & Carnarvon Offshore Basin - Macedon - Gas Field & LNG & 1,000 & 1,570 & 1,550 \\
\hline 100. & $2011 \mathrm{Q} 3$ & Carnarvon Offshore Basin - Macedon - Gas Field & LNG & 1,000 & 1,570 & 1,450 \\
\hline 101. & 2012 Q1 & Carnarvon Offshore Basin - Macedon - Gas Field & LNG & 1,000 & 1,570 & 1,470 \\
\hline 102. & 2012 Q3 & Carnarvon Offshore Basin - Macedon - Gas Field & LNG & 1,500 & 1,570 & 1,470 \\
\hline 103. & 2006 Q3 & Burrup Peninsula — Ammonia Urea Plant & Other & 900 & 1,000 & 900 \\
\hline 104. & 2007 Q1 & Burrup Peninsula - Ammonia Urea Plant & Other & 900 & 1,000 & 900 \\
\hline 105. & 2007 Q3 & Burrup Peninsula - Ammonia Urea Plant & Other & 900 & 1,000 & 900 \\
\hline 106. & 2008 Q1 & Burrup Peninsula - Ammonia Urea Plant & Other & 900 & 1,000 & 900 \\
\hline 107. & 2008 Q3 & Burrup Peninsula - Ammonia Urea Plant & Other & 900 & 1,000 & 900 \\
\hline 108. & 2009 Q1 & Burrup Peninsula - Ammonia Urea Plant & Other & 900 & 900 & 900 \\
\hline 109. & 2006 Q3 & Worsley/Boddington - Alumina Re?nery Expansion to $4.4 \mathrm{Mt} / \mathrm{a}$ & Other & 900 & 1,100 & 900 \\
\hline 110. & 2007 Q1 & Worsley/Boddington - Alumina Re?nery Expansion to $4.4 \mathrm{Mt} / \mathrm{a}$ & Other & 900 & 1,100 & 900 \\
\hline 111. & 2007 Q3 & Worsley/Boddington - Alumina Re?nery Expansion to $4.4 \mathrm{Mt} / \mathrm{a}$ & Other & 900 & 1,100 & 900 \\
\hline 112. & 2008 Q1 & Worsley/Boddington - Alumina Re?nery Expansion to $4.4 \mathrm{Mt} / \mathrm{a}$ & Other & 2,000 & 1,500 & 2,540 \\
\hline 113. & $2008 \mathrm{Q} 3$ & Worsley/Boddington - Alumina Re?nery Expansion to $4.4 \mathrm{Mt} / \mathrm{a}$ & Other & 2,500 & 1,500 & 2,600 \\
\hline 114. & 2009 Q1 & Boddington - Alumina Refinery Expansion & Other & 2,500 & 2,500 & 3,160 \\
\hline 115. & 2009 Q3 & Boddington - Alumina Refinery Expansion & Other & 2,500 & 2,500 & 2,700 \\
\hline 116. & 2010 Q1 & Boddington - Alumina Refinery Expansion & Other & 2,500 & 2,500 & 2,500 \\
\hline 117. & 2010 Q3 & Boddington - Alumina Refinery Expansion & Other & 2,500 & 2,500 & 2,400 \\
\hline 118. & $2011 \mathrm{Q} 1$ & Boddington - Alumina Refinery Expansion & Other & 2,500 & 2,500 & 2,300 \\
\hline 119. & 2006 Q3 & Yandicoogina - Iron Ore Mine EXPANSION & Iron Ore & 700 & 700 & 710 \\
\hline 120. & 2006 Q3 & Midwest Region - Weld Range - Iron Ore Mine - Midwest Region & Iron Ore & 800 & 500 & 800 \\
\hline 121. & 2007 Q1 & Midwest Region - Weld Range - Iron Ore Mine - Midwest Region & Iron Ore & 800 & 800 & 800 \\
\hline 122. & 2007 Q3 & Midwest Region - Weld Range - Iron Ore Mine - Midwest Region & Iron Ore & 800 & 800 & 579 \\
\hline 123. & 2008 Q1 & Midwest Region - Weld Range - Iron Ore Mine - Midwest Region & Iron Ore & 800 & 800 & 579 \\
\hline 124. & 2008 Q3 & Midwest Region - Weld Range - Iron Ore Mine - Midwest Region & Iron Ore & 800 & 800 & 579 \\
\hline 125. & 2009 Q1 & Midwest Region - Weld Range - Iron Ore Mine - Midwest Region & Iron Ore & 800 & 800 & 800 \\
\hline 126. & 2009 Q3 & Midwest Region - Weld Range - Iron Ore Mine - Midwest Region & Iron Ore & 800 & 800 & 800 \\
\hline 127. & 2010 Q1 & Midwest Region - Weld Range - Iron Ore Mine - Midwest Region & Iron Ore & 800 & 1,000 & 800 \\
\hline 128. & $2010 \mathrm{Q} 3$ & Midwest Region - Weld Range - Iron Ore Mine - Midwest Region & Iron Ore & 1,000 & 1,000 & 800 \\
\hline 129. & $2011 \mathrm{Q} 1$ & Midwest Region - Weld Range - Iron Ore Mine - Midwest Region & Iron Ore & 1,000 & 1,000 & 2,000 \\
\hline 130. & 2006 Q3 & Goongarrie - Kalgoorlie Nickel Proj. - Mine (laterite ore) \& Hydrometallurgi & Other & 1,400 & 1,400 & 1,400 \\
\hline 131. & 2007 Q1 & Goongarrie - Kalgoorlie Nickel Proj. - Mine (laterite ore) \& Hydrometallurgi & Other & 1,400 & 1,400 & 1,400 \\
\hline 132. & 2007 Q3 & Goongarrie - Kalgoorlie Nickel Proj. - Mine (laterite ore) \& Hydrometallurgi & Other & 1,400 & 1,400 & 1,400 \\
\hline 133. & 2008 Q1 & Goongarrie - Kalgoorlie Nickel Proj. - Mine (laterite ore) \& Hydrometallurgi & Other & 1,400 & 1,400 & 1,400 \\
\hline 134. & 2008 Q3 & Goongarrie - Kalgoorlie Nickel Proj. - Mine (laterite ore) \& Hydrometallurgi & Other & 1,400 & 1,400 & 1,400 \\
\hline 135. & 2009 Q1 & Goongarrie - Kalgoorlie Nickel Proj. - Mine (laterite ore) \& Hydrometallurgi & Other & 1,400 & 1,400 & 2,140 \\
\hline 136. & 2007 Q1 & Cape Lambert - Capacity Expansion and Stockyard Rationalisation & Iron Ore & 1,100 & 1,100 & 1,120 \\
\hline 137. & 2007 Q3 & Cape Lambert - Capacity Expansion and Stockyard Rationalisation & Iron Ore & 1,100 & 1,120 & 1,040 \\
\hline 138. & 2008 Q1 & Pilbara - Cape Lambert Port Expansion & Iron Ore & 1,100 & 1,120 & 1,090 \\
\hline 139. & $2008 \mathrm{Q} 3$ & Cape Lambert - Cape Lambert Port Expansion & Iron Ore & 1,100 & 986 & 1,120 \\
\hline 140. & 2006 Q3 & Mid West Region - Extension Hill Magnetite Mine & Iron Ore & 715 & 750 & 820 \\
\hline 141. & 2007 Q1 & Mid West Region - Extension Hill Magnetite Mine & Iron Ore & 715 & 820 & 820 \\
\hline 142. & 2007 Q3 & Mid West Region - Extension Hill Magnetite Mine & Iron Ore & 715 & 820 & 820 \\
\hline 143. & 2008 Q1 & Mid West Region - Extension Hill Magnetite Mine & Iron Ore & 715 & 820 & 820 \\
\hline 144. & $2008 \mathrm{Q} 3$ & Mid West Region - Extension Hill Magnetite Mine & Iron Ore & 715 & 820 & 820 \\
\hline
\end{tabular}


Table A1.1 Matched triplets of projects, by project size (continued)

\begin{tabular}{|c|c|c|c|c|c|c|}
\hline \multirow{2}{*}{$\begin{array}{l}\text { Row } \\
\text { no. } \\
(1) \\
\end{array}$} & \multirow{2}{*}{$\begin{array}{c}\text { Year/ } \\
\text { Quarter } \\
(2)\end{array}$} & \multirow{2}{*}{$\begin{array}{c}\text { Project } \\
\text { (3) }\end{array}$} & \multirow{2}{*}{$\begin{array}{c}\text { Industry } \\
\text { (4) }\end{array}$} & \multicolumn{3}{|c|}{ Cost $(\$ \mathrm{~m})$} \\
\hline & & & & $\begin{array}{l}\text { PR } \\
(5)\end{array}$ & $\begin{array}{l}\text { IM } \\
(6)\end{array}$ & $\begin{array}{l}\text { BR } \\
\text { (7) }\end{array}$ \\
\hline 145. & 2009 Q1 & Mid West Region - Extension Hill Magnetite Mine & Iron Ore & 715 & 820 & 820 \\
\hline 146. & 2009 Q3 & Mid West Region - Extension Hill Magnetite Mine & Iron Ore & 715 & 820 & 2,000 \\
\hline 147. & 2010 Q1 & Mid West Region - Extension Hill Magnetite Mine & Iron Ore & 715 & 820 & 2,000 \\
\hline 148. & $2011 \mathrm{Q} 1$ & Mid West Region - Extension Hill Magnetite Mine & Iron Ore & 2,000 & 2,000 & 2,500 \\
\hline 149. & $2011 \mathrm{Q} 3$ & Mid West Region - Extension Hill Magnetite Mine & Iron Ore & 2,000 & 2,000 & 2,900 \\
\hline 150. & 2012 Q1 & Mid West Region - Extension Hill Magnetite Mine & Iron Ore & 2,000 & 2,000 & 2,900 \\
\hline 151. & 2012 Q3 & Mid West Region - Extension Hill Magnetite Mine & Iron Ore & 2,000 & 2,000 & 2,900 \\
\hline 152. & 2006 Q3 & Great Southern Region - Southdown Magnetite - Iron Ore Project & Iron Ore & 560 & 1,700 & 803 \\
\hline 153. & 2007 Q1 & Great Southern Region - Southdown Magnetite - Iron Ore Project & Iron Ore & 560 & 893 & 803 \\
\hline 154. & $2007 \mathrm{Q} 3$ & Great Southern Region - Southdown Magnetite - Iron Ore Project & Iron Ore & 893 & 893 & 744 \\
\hline 155. & 2008 Q1 & Great Southern Region - Southdown Magnetite - Iron Ore Project & Iron Ore & 893 & 893 & 964 \\
\hline 156. & $2008 \mathrm{Q} 3$ & Great Southern Region - Southdown Magnetite - Iron Ore Project & Iron Ore & 839 & 1,119 & 987 \\
\hline 157. & 2009 Q1 & Great Southern Region - Southdown Magnetite - Iron Ore Project & Iron Ore & 839 & 1,119 & 1,200 \\
\hline 158. & 2009 Q3 & Great Southern Region - Southdown Magnetite - Iron Ore Project & Iron Ore & 839 & 1,119 & 1,900 \\
\hline 159. & 2010 Q1 & Great Southern Region - Southdown Magnetite - Iron Ore Project & Iron Ore & 1,600 & 1,700 & 1,800 \\
\hline 160. & $2011 \mathrm{Q} 3$ & Great Southern Region - Southdown Magnetite - Iron Ore Project & Iron Ore & 2,570 & 2,570 & 2,600 \\
\hline 161. & 2012 Q1 & Great Southern Region - Southdown Magnetite - Iron Ore Project & Iron Ore & 2,750 & 2,570 & 2,900 \\
\hline 162. & $2012 \mathrm{Q} 3$ & Great Southern Region - Southdown Magnetite - Iron Ore Project & Iron Ore & 1,600 & 2,880 & 2,880 \\
\hline 163. & 2006 Q3 & Argyle - Underground Diamond Mine & Other & 1,200 & 1,200 & 1,220 \\
\hline 164. & 2007 Q1 & Argyle - Underground Diamond Mine & Other & 1,200 & 1,220 & 1,220 \\
\hline 165. & 2007 Q3 & Argyle - Underground Diamond Mine & Other & 1,200 & 1,220 & 1,800 \\
\hline 166. & 2008 Q1 & Argyle - Underground Diamond Mine & Other & 1,200 & 1,700 & 1,700 \\
\hline 167. & $2008 \mathrm{Q} 3$ & Kimberley - Argyle - Argyle Diamond Mine & Other & 1,200 & 1,700 & 1,760 \\
\hline 168. & 2009 Q1 & Kimberley - Argyle - Argyle Diamond Mine & Other & 1,200 & 1,700 & 2,140 \\
\hline 169. & 2009 Q3 & Kimberley - Argyle - Argyle Diamond Mine & Other & 1,200 & 1,700 & 1,800 \\
\hline 170. & 2010 Q1 & East Kimberley - Argyle Diamond Mine (and Underground Expansion) & Other & 1,200 & 1,700 & 1,700 \\
\hline 171. & 2007 Q1 & Mid West Region - Karara Magnetite Mine & Iron Ore & 1,000 & 1,100 & 1,000 \\
\hline 172. & 2007 Q3 & Mid West Region - Karara Magnetite Mine & Iron Ore & 1,000 & 1,700 & 1,600 \\
\hline 173. & $2008 \mathrm{Q} 1$ & Mid West Region - Mt Karara Magnetite Mine & Iron Ore & 1,000 & 1,700 & 1,600 \\
\hline 174. & 2008 Q3 & Mid West Region - Mt Karara Magnetite Mine & Iron Ore & 1,000 & 1,700 & 1,600 \\
\hline 175. & 2009 Q1 & Mid West Region - Mt Karara Magnetite Mine & Iron Ore & 1,700 & 1,700 & 1,700 \\
\hline 176. & 2009 Q3 & Mid West Region - Mt Karara Magnetite Mine & Iron Ore & 1,800 & 1,800 & 1,700 \\
\hline 177. & 2010 Q1 & Mid West Region - Mt Karara Magnetite Mine & Iron Ore & 1,800 & 1,800 & 1,900 \\
\hline 178. & 2010 Q3 & Mid West Region - Mt Karara Magnetite Mine & Iron Ore & 1,975 & 1,970 & 2,000 \\
\hline 179. & 2011 Q1 & Mid West Region - Mt Karara Magnetite Mine & Iron Ore & 1,975 & 2,700 & 2,600 \\
\hline 180. & $2011 \mathrm{Q} 3$ & Mid West Region - Mt Karara Magnetite Mine & Iron Ore & 1,975 & 2,700 & 2,600 \\
\hline 181. & 2012 Q1 & Mid West Region - Mt Karara Magnetite Mine & Iron Ore & 1,975 & 2,570 & 2,600 \\
\hline 182. & 2006 Q3 & Pilbara - Spinifex Ridge $\mathrm{Mo} / \mathrm{Cu}$ mine & Other & 622 & 622 & 622 \\
\hline 183. & 2007 Q1 & Pilbara - Spinifex Ridge $\mathrm{Mo} / \mathrm{Cu}$ mine & Other & 622 & 622 & 622 \\
\hline 184. & 2007 Q3 & Pilbara - Spinifex Ridge Mo/Cu mine & Other & 622 & 622 & 1,080 \\
\hline 185. & 2008 Q1 & Pilbara - Spinifex Ridge $\mathrm{Mo} / \mathrm{Cu}$ mine & Other & 1,084 & 1,100 & 1,080 \\
\hline 186. & $2008 \mathrm{Q} 3$ & Pilbara - Spinifex Ridge Mo/Cu mine & Other & 1,084 & 1,100 & 1,260 \\
\hline 187. & 2009 Q1 & Pilbara - Spinifex Ridge $\mathrm{Mo} / \mathrm{Cu}$ mine & Other & 1,084 & 1,084 & 1,260 \\
\hline 188. & 2009 Q3 & Pilbara - Spinifex Ridge $\mathrm{Mo} / \mathrm{Cu}$ mine & Other & 1,084 & 1,084 & 604 \\
\hline 189. & 2010 Q1 & Pilbara - Spinifex Ridge Mo/Cu mine & Other & 1,084 & 542 & 604 \\
\hline 190. & 2006 Q3 & Angel (Carnarvon Offshore Basin) - Gas Field & LNG & 1,600 & 1,500 & 1,600 \\
\hline 191. & 2007 Q1 & Angel (Carnarvon Offshore Basin) - Gas Field & LNG & 1,600 & 1,600 & 1,600 \\
\hline 192. & $2007 \mathrm{Q} 3$ & Angel (Carnarvon Offshore Basin) - Gas Field & LNG & 1,600 & 1,600 & 1,430 \\
\hline 193. & 2008 Q1 & Angel (Carnarvon Offshore Basin) - Gas Field & LNG & 1,600 & 1,600 & 1,380 \\
\hline 194. & 2006 Q3 & Stybarrow (Carnarvon Offshore Basin) - Oil Field & LNG & 815 & 810 & 803 \\
\hline 195. & 2007 Q1 & Stybarrow (Carnarvon Offshore Basin) - Oil Field & LNG & 815 & 810 & 803 \\
\hline 196. & 2007 Q3 & Stybarrow (Carnarvon Offshore Basin) - Oil Field & LNG & 860 & 860 & 905 \\
\hline 197. & 2008 Q3 & Tom Price - Brockman 4 Iron Ore Mine & Iron Ore & 1,521 & 1,500 & 1,760 \\
\hline 198. & 2009 Q1 & Pilbara - Brockman Syncline 4 Iron Ore Mine & Iron Ore & 1,521 & 1,520 & 2,100 \\
\hline 199. & 2009 Q3 & Pilbara - Brockman Syncline 4 Iron Ore Mine & Iron Ore & 2,000 & 1,520 & 1,800 \\
\hline 200. & 2010 Q1 & Pilbara - Brockman Syncline 4 Iron Ore Mine & Iron Ore & 2,000 & 1,638 & 1,700 \\
\hline 201. & $2006 \mathrm{Q} 3$ & vincent (Carnarvon Offshore Basin) - Oil Field & LNG & 1,000 & 1,000 & 1,000 \\
\hline 202. & 2007 Q1 & vincent (Carnarvon Offshore Basin) - Oil Field & LNG & 1,000 & 1,000 & 1,000 \\
\hline 203. & 2007 Q3 & vincent (Carnarvon Offshore Basin) - Oil Field & LNG & 1,000 & 1,000 & 1,000 \\
\hline 204. & 2008 Q1 & vincent (Carnarvon Offshore Basin) - Oil Field & LNG & 1,000 & 1,000 & 1,000 \\
\hline 205. & 2007 Q1 & Jack Hills & Iron Ore & 1,700 & 1,760 & 1,760 \\
\hline 206. & 2007 Q3 & Jack Hills & Iron Ore & 750 & 1,760 & 3,000 \\
\hline 207. & 2008 Q1 & Jack Hills & Iron Ore & 750 & 3,000 & 1,500 \\
\hline 208. & $2008 \mathrm{Q} 3$ & Jack Hills & Iron Ore & 750 & 3,000 & 1,500 \\
\hline 209. & 2009 Q1 & Jack Hills & Iron Ore & 750 & 3,000 & 1,500 \\
\hline 210 & 2009 Q3 & Jack Hills & Iron Ore & 750 & 3,000 & 1,500 \\
\hline 211. & 2010 Q1 & Jack Hills & Iron Ore & 750 & 2,000 & 1,500 \\
\hline 212. & 2010 Q3 & Jack Hills & Iron Ore & 2,000 & 2,000 & 1,500 \\
\hline 213. & 2011 Q1 & Jack Hills & Iron Ore & 2,000 & 4,300 & 1,500 \\
\hline 214. & $2011 \mathrm{Q} 3$ & Jack Hills & Iron Ore & 2,000 & 4,300 & 2,000 \\
\hline 215. & 2012 Q1 & Jack Hills & Iron Ore & 2,000 & 4,300 & 2,000 \\
\hline 216. & 2007 Q1 & Pilbara - Dampier Port Expansion & Iron Ore & 920 & 940 & 1,040 \\
\hline 217. & 2008 Q1 & van Gogh (Carnarvon Offshore Basin) - Oil Field & LNG & 600 & 600 & 700 \\
\hline
\end{tabular}


Table A1.1 Matched triplets of projects, by project size (continued)

\begin{tabular}{|c|c|c|c|c|c|c|}
\hline \multirow{3}{*}{$\begin{array}{l}\text { Row } \\
\text { no. } \\
(1)\end{array}$} & \multirow{3}{*}{$\begin{array}{c}\text { Year/ } \\
\text { Quarter } \\
(2)\end{array}$} & \multirow{3}{*}{$\begin{array}{c}\text { Project } \\
\text { (3) }\end{array}$} & \multirow{3}{*}{$\begin{array}{c}\text { Industry } \\
\text { (4) }\end{array}$} & \multicolumn{3}{|c|}{ Cost $(\$ m)$} \\
\hline & & & & PR & IM & BR \\
\hline & & & & $(5)$ & $(6)$ & (7) \\
\hline 218. & $2008 \mathrm{Q} 3$ & Carnarvon Offshore Basin - van Gogh - Oil Field & LNG & 600 & 600 & 700 \\
\hline 219. & 2009 Q1 & Carnarvon Offshore Basin - van Gogh - Oil Field & LNG & 600 & 600 & 780 \\
\hline 220. & 2009 Q3 & Carnarvon Offshore Basin - van Gogh - Oil Field & LNG & 600 & 600 & 658 \\
\hline 221. & 2008 Q1 & Pilbara - Devil Creek Development Project & LNG & 600 & 750 & 842 \\
\hline 222. & 2008 Q3 & Pilbara - Devil Creek Development Project & LNG & 600 & 800 & 875 \\
\hline 223. & 2009 Q1 & Pilbara - Devil Creek Development Project & LNG & 800 & 800 & 1,060 \\
\hline 224. & 2009 Q3 & Pilbara - Devil Creek Development Project & LNG & 800 & 850 & 896 \\
\hline 225. & 2010 Q1 & Pilbara - Devil Creek Development Project & LNG & 800 & 850 & 845 \\
\hline 226. & 2010 Q3 & Pilbara - Devil Creek Development Project & LNG & 800 & 850 & 1,080 \\
\hline 227. & $2011 \mathrm{Q} 1$ & Pilbara - Devil Creek Development Project & LNG & 800 & 850 & 1,080 \\
\hline 228. & 2011 Q3 & Pilbara - Devil Creek Development Project & LNG & 800 & 850 & 1,050 \\
\hline 229. & 2009 Q1 & Goldfields - Tropicana Gold project & Other & 500 & 1,000 & 500 \\
\hline 230. & 2009 Q3 & Goldfields - Tropicana Gold project & Other & 500 & 1,000 & 500 \\
\hline 231. & 2010 Q1 & Kalgoorlie (330kms North East) - Tropicana Gold Project & Other & 700 & 1,000 & 520 \\
\hline 232. & 2010 Q3 & Kalgoorlie (330kms North East) - Tropicana Gold Project & Other & 700 & 1,000 & 600 \\
\hline 233. & 2011 Q1 & Kalgoorlie (330kms North East) - Tropicana Gold Project & Other & 700 & 700 & 725 \\
\hline 234. & $2011 \mathrm{Q} 3$ & Kalgoorlie (330kms North East) - Tropicana Gold Project & Other & 700 & 700 & 665 \\
\hline 235. & 2012 Q1 & Kalgoorlie (330kms North East) - Tropicana Gold Project & Other & 700 & 700 & 715 \\
\hline 236. & 2012 Q3 & Kalgoorlie (330kms North East) - Tropicana Gold Project & Other & 700 & 700 & 775 \\
\hline 237. & 2009 Q1 & Burrup Peninsula - Burrup Ammonium Nitrate Plant & Other & 600 & 900 & 500 \\
\hline 238. & 2009 Q3 & Burrup Peninsula - Burrup Ammonium Nitrate Plant & Other & 600 & 900 & 500 \\
\hline 239. & 2010 Q1 & Burrup Industrial Estate Site D - Burrup Nitrates ammonium nitrate plant & Other & 600 & 900 & 600 \\
\hline 240. & 2010 Q3 & Burrup Industrial Estate Site D - Burrup Nitrates ammonium nitrate plant & Other & 600 & 900 & 600 \\
\hline 241. & $2011 \mathrm{Q} 1$ & Burrup Industrial Estate Site D - Burrup Nitrates ammonium nitrate plant & Other & 600 & 600 & 600 \\
\hline 242. & $2011 \mathrm{Q} 3$ & Burrup Industrial Estate Site D - Burrup Nitrates ammonium nitrate plant & Other & 600 & 600 & 600 \\
\hline 243. & 2012 Q1 & Burrup Industrial Estate Site D - Burrup Nitrates ammonium nitrate plant & Other & 600 & 600 & 600 \\
\hline 244. & 2012 Q3 & Burrup Industrial Estate Site D - Burrup Nitrates ammonium nitrate plant & Other & 600 & 600 & 775 \\
\hline 245. & 2012 Q1 & Pilbara - Hope Downs 4 Iron Ore Mine & Iron Ore & 1,600 & 1,330 & 2,100 \\
\hline 246. & 2012 Q3 & Pilbara - Hope Downs 4 Iron Ore Mine & Iron Ore & 1,600 & 1,330 & 2,040 \\
\hline \multicolumn{7}{|c|}{ Н } \\
\hline 247. & 2006 Q3 & Boddington - Gold Mine (Wandoo Expansion) & Other & 2,000 & 2,000 & 2,000 \\
\hline 248. & 2007 Q1 & Boddington - Gold Mine (Wandoo Expansion) & Other & 2,000 & 2,000 & 2,000 \\
\hline 249. & 2007 Q3 & Boddington - Gold Mine (Wandoo Expansion) & Other & 2,000 & 2,000 & 2,000 \\
\hline 250. & 2008 Q1 & Boddington - Gold Mine (Wandoo Expansion) & Other & 2,000 & 2,000 & 2,400 \\
\hline 251. & 2008 Q3 & Boddington - Gold Mine (Wandoo Expansion) & Other & 2,000 & 2,000 & 2,900 \\
\hline 252. & 2009 Q1 & Boddington - Gold Mine (Wandoo Expansion) & Other & 2,000 & 4,500 & 3,700 \\
\hline 253. & 2006 Q3 & Fortescue (Cape Preston) — Mine and HBI Plant & Iron Ore & 2,000 & 1,800 & 2,000 \\
\hline 254. & 2007 Q1 & Fortescue (Cape Preston) — Mine and HBI Plant & Iron Ore & 2,000 & 2,000 & 2,630 \\
\hline 255. & 2006 Q3 & Ravensthorpe - Lateritic Nickel Mine and Hydro-metallurgical Process. Plant & Other & 1,800 & 2,680 & 2,250 \\
\hline 256. & 2007 Q1 & Ravensthorpe - Lateritic Nickel Mine and Hydro-metallurgical Process. Plant & Other & 1,800 & 2,800 & 2,900 \\
\hline 257. & 2007 Q3 & Ravensthorpe - Lateritic Nickel Mine and Hydro-metallurgical Process. Plant & Other & 2,200 & 2,900 & 2,600 \\
\hline 258. & 2006 Q3 & Gorgon (Carnarvon Offshore Basin) — Gas and Condensate Field & LNG & 11,000 & 14,600 & 15,000 \\
\hline 259. & 2007 Q1 & Barrow Island (Carnarvon Offshore Basin) - Gorgon LNG & LNG & 11,000 & 15,000 & 15,000 \\
\hline 260. & 2009 Q3 & Carnarvon Offshore Basin - Barrow Island -Gorgon LNG & LNG & 43,000 & 43,000 & 43,000 \\
\hline 261. & 2010 Q1 & Carnarvon Offshore Basin - Barrow Island -Gorgon LNG & LNG & 43,000 & 50,000 & 43,000 \\
\hline 262. & 2010 Q3 & Carnarvon Offshore Basin - Barrow Island -Gorgon LNG & LNG & 43,000 & 43,000 & 43,000 \\
\hline 263. & 2011 Q1 & Carnarvon Offshore Basin - Barrow Island -Gorgon LNG & LNG & 43,000 & 43,000 & 43,000 \\
\hline 264. & 2011 Q3 & Carnarvon Offshore Basin - Barrow Island -Gorgon LNG & LNG & 43,000 & 43,000 & 43,000 \\
\hline 265. & 2012 Q1 & Carnarvon Offshore Basin - Barrow Island -Gorgon LNG & LNG & 43,000 & 43,000 & 43,000 \\
\hline 266. & 2012 Q3 & Carnarvon Offshore Basin - Barrow Island -Gorgon LNG & LNG & 43,000 & 43,000 & 43,000 \\
\hline 267. & 2006 Q3 & North West Shelf — Project Expansion:5th LNG Train & LNG & 2,000 & 2,425 & 2,425 \\
\hline 268. & 2007 Q1 & North West Shelf — Project Expansion:5th LNG Train & LNG & 2,425 & 2,425 & 2,425 \\
\hline 269. & 2007 Q3 & North West Shelf — Project Expansion:5th LNG Train & LNG & 2,425 & 2,425 & 2,600 \\
\hline 270. & 2008 Q1 & North West Shelf — Project Expansion:5th LNG Train & LNG & 2,425 & 2,425 & 2,600 \\
\hline 271. & 2006 Q3 & Pilbara - Iron Ore Mine, Rail and Port Development & Iron Ore & 2,500 & 1,950 & 1,920 \\
\hline 272. & 2007 Q1 & Pilbara - Iron Ore Mine, Rail and Port Development & Iron Ore & 3,200 & 1,950 & 2,780 \\
\hline 273. & 2007 Q3 & Pilbara - Iron Ore Mine, Rail and Port Development & Iron Ore & 3,200 & 2,056 & 2,880 \\
\hline 274. & 2008 Q1 & Pilbara - Iron Ore Mine, Rail and Port Development & Iron Ore & 3,200 & 2,056 & 3,100 \\
\hline 275. & 2006 Q3 & Pilbara - Rapid Growth Project 3 & Iron Ore & 2,000 & 1,700 & 2,050 \\
\hline 276. & 2007 Q1 & Pilbara - Rapid Growth Project 3 & Iron Ore & 2,000 & 2,050 & 2,010 \\
\hline 277. & 2007 Q3 & Pilbara - Rapid Growth Project 3 & Iron Ore & 2,000 & 2,050 & 1,820 \\
\hline 278. & 2006 Q3 & Onslow - LNG Plant & LNG & 5,000 & 5,000 & 5,000 \\
\hline 279. & 2007 Q1 & Onslow - LNG Plant & LNG & 5,000 & 5,000 & 5,000 \\
\hline 280. & 2006 Q3 & Carnarvon Basin - Pluto LNG & LNG & 5,000 & 5,000 & 5,000 \\
\hline 281. & 2007 Q1 & Carnarvon Basin - Pluto LNG & LNG & 5,000 & 6,000 & 5,000 \\
\hline 282. & 2007 Q3 & Carnarvon Basin - Pluto LNG & LNG & 6,000 & 11,200 & 12,000 \\
\hline 283. & 2008 Q1 & Carnarvon Basin - Pluto LNG & LNG & 11,200 & 11,200 & 12,000 \\
\hline 284. & 2008 Q3 & Carnarvon Basin - Pluto LNG & LNG & 11,200 & 11,200 & 12,000 \\
\hline 285. & 2009 Q1 & Carnarvon Basin - Pluto LNG & LNG & 11,200 & 11,200 & 12,000 \\
\hline 286. & 2009 Q3 & Carnarvon Basin - Pluto LNG & LNG & 11,200 & 11,200 & 12,000 \\
\hline 287. & 2010 Q1 & Carnarvon Basin - Pluto LNG & LNG & 12,000 & 12,320 & 12,100 \\
\hline 288. & 2010 Q3 & Carnarvon Basin - Pluto LNG & LNG & 12,000 & 12,320 & 12,100 \\
\hline 289. & 2006 Q3 & Pilbara - Rapid Growth Project 4 & Iron Ore & 1,800 & 1,800 & 2,200 \\
\hline
\end{tabular}


Table A1.1 Matched triplets of projects, by project size (continued)

\begin{tabular}{|c|c|c|c|c|c|c|}
\hline \multirow{3}{*}{$\begin{array}{l}\text { Row } \\
\text { no. } \\
(1)\end{array}$} & \multirow{3}{*}{$\begin{array}{c}\text { Year/ } \\
\text { Quarter } \\
(2)\end{array}$} & \multirow{3}{*}{$\begin{array}{c}\text { Project } \\
\text { (3) }\end{array}$} & \multirow{3}{*}{$\begin{array}{c}\text { Industry } \\
\text { (4) }\end{array}$} & \multicolumn{3}{|c|}{ Cost $(\$ \mathrm{~m})$} \\
\hline & & & & PR & $\mathrm{IM}$ & BR \\
\hline & & & & $(5)$ & $(6)$ & (7) \\
\hline 290. & 2007 Q1 & Pilbara - Rapid Growth Project 4 & Iron Ore & 1,800 & 2,200 & 2,820 \\
\hline 291. & 2007 Q3 & Pilbara - Rapid Growth Project 4 & Iron Ore & 2,600 & 2,200 & 2,550 \\
\hline 292. & 2008 Q1 & Pilbara - Rapid Growth Project 4 & Iron Ore & 2,600 & 2,200 & 2,470 \\
\hline 293. & 2008 Q3 & Pilbara - Rapid Growth Project 4 & Iron Ore & 2,600 & 2,000 & 2,520 \\
\hline 294. & 2009 Q1 & Pilbara - Rapid Growth Project 4 & Iron Ore & 2,840 & 2,840 & 3,060 \\
\hline 295. & 2009 Q3 & Pilbara - Rapid Growth Project 4 & Iron Ore & 2,597 & 2,597 & 2,600 \\
\hline 296. & 2007 Q3 & Pyrenees Development (Carnarvon Offshore Basin)- Oil Fields & LNG & 2,000 & 2,000 & 2,020 \\
\hline 297. & 2008 Q1 & Pyrenees Development (Carnarvon Offshore Basin)- Oil Fields & LNG & 2,000 & 2,000 & 1,930 \\
\hline 298. & $2008 \mathrm{Q} 3$ & Carnarvon Offshore Basin - Pyrenees - Oil Fields & LNG & 2,000 & 2,000 & 2,180 \\
\hline 299. & 2009 Q1 & Carnarvon Offshore Basin - Pyrenees - Oil Fields & LNG & 2,000 & 2,000 & 2,400 \\
\hline 300. & 2009 Q3 & Carnarvon Offshore Basin - Pyrenees - Oil Fields & LNG & 2,000 & 2,000 & 2,000 \\
\hline 301. & 2006 Q3 & Browse Basin - Ichthys (Browse Offshore Basin) & LNG & 8,000 & 8,000 & 8,000 \\
\hline 302. & 2007 Q1 & Browse Basin - Ichthys (Browse Offshore Basin) & LNG & 8,000 & 8,000 & 8,000 \\
\hline 303. & 2007 Q3 & Browse Basin - Ichthys (Browse Offshore Basin) & LNG & 8,000 & 8,000 & 8,000 \\
\hline 304. & 2008 Q3 & Pilbara - West Pilbara Iron Ore Project & Iron Ore & 3,000 & 4,100 & 4,150 \\
\hline 305. & 2009 Q1 & Pilbara - West Pilbara Iron Ore Project & Iron Ore & 3,900 & 4,100 & 5,000 \\
\hline 306. & 2009 Q3 & Pilbara - West Pilbara Iron Ore Project & Iron Ore & 3,900 & 4,100 & 4,200 \\
\hline 307. & 2010 Q1 & Pilbara - West Pilbara Iron Ore Project & Iron Ore & 4,000 & 4,810 & 4,200 \\
\hline 308. & 2010 Q3 & Pilbara - West Pilbara Iron Ore Project & Iron Ore & 4,000 & 4,810 & 5,800 \\
\hline 309. & 2011 Q1 & Pilbara - West Pilbara Iron Ore Project & Iron Ore & 4,000 & 4,810 & 5,800 \\
\hline 310. & 2011 Q3 & Pilbara - West Pilbara Iron Ore Project & Iron Ore & 4,000 & 4,810 & 5,800 \\
\hline 311. & 2012 Q1 & Pilbara - West Pilbara Iron Ore Project & Iron Ore & 4,000 & 5,800 & 5,800 \\
\hline 312. & 2012 Q3 & Pilbara - West Pilbara Iron Ore Project & Iron Ore & 6,000 & 7,400 & 7,400 \\
\hline 313. & 2009 Q3 & pilbara - Sino Iron pellet project & Iron Ore & 5,200 & 5,200 & 4,200 \\
\hline 314. & 2010 Q1 & pilbara - Sino Iron pellet project & Iron Ore & 5,200 & 5,200 & 5,900 \\
\hline 315. & 2010 Q3 & pilbara - Sino Iron pellet project & Iron Ore & 5,200 & 5,200 & 5,800 \\
\hline 316. & $2008 \mathrm{Q} 3$ & Pilbara - Rapid Growth Project 5 & Iron Ore & 9,000 & 3,440 & 8,300 \\
\hline 317. & 2009 Q1 & Pilbara - Rapid Growth Project 5 & Iron Ore & 7,365 & 7,365 & 8,100 \\
\hline 318. & 2009 Q3 & Pilbara - Rapid Growth Project 5 & Iron Ore & 6,740 & 6,740 & 6,800 \\
\hline 319. & 2010 Q1 & Pilbara - Rapid Growth Project 5 & Iron Ore & 5,300 & 6,740 & 6,400 \\
\hline 320. & 2010 Q3 & Pilbara - Rapid Growth Project 5 & Iron Ore & 4,800 & 6,740 & 6,300 \\
\hline 321. & $2011 \mathrm{Q} 1$ & Pilbara - Rapid Growth Project 5 & Iron Ore & 4,800 & 6,740 & 5,800 \\
\hline 322. & 2009 Q1 & Cape Preston - Magnetite Iron Ore Mine & Iron Ore & 2,700 & 2,600 & 2,700 \\
\hline 323. & 2009 Q3 & Cape Preston Balmoral South -Australasian Resources & Iron Ore & 2,700 & 2,600 & 2,700 \\
\hline 324. & 2010 Q1 & Pilbara - Cape Preston - Balmoral South Iron Ore Project & Iron Ore & 2,700 & 2,600 & 2,700 \\
\hline 325. & 2010 Q1 & Pilbara - Wheatstone LNG Development & LNG & 3,000 & 10,000 & 20,200 \\
\hline 326. & 2010 Q3 & Pilbara - Wheatstone LNG Development & LNG & 23,000 & 10,000 & 19,800 \\
\hline 327. & $2011 \mathrm{Q} 1$ & Pilbara - Wheatstone LNG Development & LNG & 23,000 & 10,000 & 18,400 \\
\hline 328. & 2011 Q3 & Pilbara - Wheatstone LNG Development & LNG & 23,000 & 29,000 & 29,000 \\
\hline 329. & 2012 Q3 & Pilbara - Wheatstone LNG Development & LNG & 29,000 & 29,000 & 29,000 \\
\hline 330. & $2011 \mathrm{Q} 3$ & Pilbara - Cape Lambert Iron Ore Project & Iron Ore & 3,700 & 3,700 & 3,700 \\
\hline 331. & 2012 Q1 & Pilbara - Cape Lambert Iron Ore Project & Iron Ore & 3,700 & 3,700 & 3,700 \\
\hline 332. & 2012 Q3 & Pilbara - Cape Lambert Iron Ore Project & Iron Ore & 3,700 & 3,700 & 3,700 \\
\hline 333. & 2009 Q3 & Carnarvon Offshore Basin - North Rankin Redevelopment & LNG & 5,000 & 5,000 & 6,100 \\
\hline 334. & 2010 Q1 & Carnarvon Offshore Basin - North Rankin Redevelopment & LNG & 5,000 & 5,000 & 5,800 \\
\hline 335. & 2010 Q3 & Carnarvon Offshore Basin - North Rankin Redevelopment & LNG & 5,000 & 5,000 & 5,700 \\
\hline 336. & $2011 \mathrm{Q} 1$ & Carnarvon Offshore Basin - North Rankin Redevelopment & LNG & 5,000 & 5,000 & 5,200 \\
\hline 337. & $2011 \mathrm{Q} 3$ & Carnarvon Offshore Basin - North Rankin Redevelopment & LNG & 5,000 & 5,000 & 5,000 \\
\hline 338. & 2012 Q1 & Carnarvon Offshore Basin - North Rankin Redevelopment & LNG & 5,000 & 5,000 & 5,100 \\
\hline 339. & 2012 Q3 & Carnarvon Offshore Basin - North Rankin Redevelopment & LNG & 5,000 & 5,000 & 5,000 \\
\hline 340. & 2009 Q3 & Oakajee - Oakajee Industrial Estate \& Port Project & Iron Ore & 4,000 & 4,000 & 3,500 \\
\hline 341. & 2010 Q1 & Oakajee - Oakajee Industrial Estate \& Port Project & Iron Ore & 4,000 & 4,370 & 4,300 \\
\hline 342. & 2010 Q3 & Oakajee - Oakajee Industrial Estate \& Port Project & Iron Ore & 4,000 & 4,370 & 4,300 \\
\hline 343. & 2011 Q1 & Oakajee - Oakajee Industrial Estate \& Port Project & Iron Ore & 4,000 & 5,239 & 5,200 \\
\hline 344. & 2012 Q1 & Oakajee - Oakajee Industrial Estate \& Port Project & Iron Ore & 4,000 & 5,940 & 5,900 \\
\hline 345. & 2012 Q3 & Oakajee - Oakajee Industrial Estate \& Port Project & Iron Ore & 4,000 & 10,000 & 5,000 \\
\hline 346. & 2010 Q1 & Wanaea/Cossack (Carnarvon Offshore Basin) -Oil and Gas Fields & LNG & 1,800 & 1,800 & 1,700 \\
\hline 347. & 2010 Q3 & Wanaea/Cossack (Carnarvon Offshore Basin) -Oil and Gas Fields & LNG & 1,800 & 1,800 & 1,600 \\
\hline 348. & $2011 \mathrm{Q} 1$ & Wanaea/Cossack (Carnarvon Offshore Basin) -Oil and Gas Fields & LNG & 1,800 & 1,800 & 1,500 \\
\hline 349. & 2011 Q3 & Pilbara - Cape Lambert Port B Expansion & Iron Ore & 3,700 & 890 & 3,100 \\
\hline 350. & 2010 Q3 & Port Wallcott - Cape Lambert Expansion & Iron Ore & 3,000 & 890 & 3,400 \\
\hline 351. & 2011 Q1 & Solomon - Pilbara - Solomon Hub Stage 1 & Iron Ore & 4,000 & 4,000 & 2,370 \\
\hline 352. & 2011 Q3 & Solomon - Pilbara - Solomon Hub Stage 1 & Iron Ore & 4,000 & 4,000 & 2,600 \\
\hline 353. & 2012 Q1 & Solomon - Pilbara - Solomon Hub Stage 1 & Iron Ore & 4,000 & 4,000 & 2,700 \\
\hline 354. & 2012 Q3 & Solomon - Pilbara - Solomon Hub Stage 1 & Iron Ore & 9,000 & 4,000 & 3,100 \\
\hline
\end{tabular}

Notes:

1. PR, IM and BR are abbreviations for the Prospect, Investment Monitor and ABARE/BREE databases, respectively.

2. Q1 and Q3 in column 2 refer to the March and September quarters where the matched data recorded. 


\section{A-11}

Table A2.1 Impulse response functions

\begin{tabular}{|c|c|c|c|c|c|c|c|c|c|}
\hline \multirow{3}{*}{$\begin{array}{l}\text { Sources } \\
\text { s to } r \\
(1) \\
\text { PR to PR }\end{array}$} & \multirow{3}{*}{$\begin{array}{c}\text { Period } \\
\\
(2) \\
1\end{array}$} & \multicolumn{4}{|c|}{ Intercepts included } & \multicolumn{4}{|c|}{ Intercepts supressed } \\
\hline & & \multicolumn{2}{|c|}{$\begin{array}{l}\text { Response of s to } \\
\text { unfactorised } 1 \mathrm{SD} \\
\text { shock in } \mathrm{r} \\
\text { (3) }\end{array}$} & \multicolumn{2}{|c|}{$\begin{array}{l}\text { Response of s to } \\
\text { factorised } 1 \mathrm{SD} \\
\text { shock in } \mathrm{r} \\
\text { (4) }\end{array}$} & \multicolumn{2}{|c|}{$\begin{array}{l}\text { Response of s to } \\
\text { unfactorised } 1 \mathrm{SD} \\
\text { shock in } \mathrm{r} \\
\text { (5) }\end{array}$} & \multicolumn{2}{|c|}{$\begin{array}{l}\text { Response of } s \text { to } \\
\text { factorised } 1 \mathrm{SD} \\
\text { shock in } \mathrm{r} \\
\text { (6) }\end{array}$} \\
\hline & & 0.198 & $(0.008)$ & 0.198 & $(0.008)$ & 0.204 & $(0.009)$ & 0.204 & $(0.009)$ \\
\hline & 2 & -0.009 & $(0.011)$ & -0.001 & $(0.011)$ & -0.002 & $(0.012)$ & 0.011 & $(0.012)$ \\
\hline \multirow[t]{2}{*}{ PR to IM } & 1 & 0.000 & $(0.000)$ & 0.000 & $(0.000)$ & 0.000 & $(0.000)$ & 0.000 & $(0.000)$ \\
\hline & 2 & 0.003 & $(0.013)$ & 0.008 & $(0.013)$ & 0.012 & $(0.013)$ & 0.019 & $(0.013)$ \\
\hline \multirow[t]{2}{*}{ PR to BR } & 1 & 0.000 & $(0.000)$ & 0.000 & $(0.000)$ & 0.000 & $(0.000)$ & 0.000 & $(0.000)$ \\
\hline & 2 & 0.027 & $(0.014)$ & 0.026 & (0.013) & 0.034 & $(0.014)$ & 0.032 & $(0.013)$ \\
\hline \multirow[t]{2}{*}{ IM to PR } & 1 & 0.000 & $(0.000)$ & 0.026 & $(0.010)$ & 0.000 & $(0.000)$ & 0.033 & $(0.011)$ \\
\hline & 2 & 0.018 & $(0.010)$ & 0.022 & $(0.010)$ & 0.023 & $(0.010)$ & 0.031 & $(0.010)$ \\
\hline \multirow[t]{2}{*}{ IM to IM } & 1 & 0.174 & $(0.007)$ & 0.172 & $(0.007)$ & 0.178 & $(0.007)$ & 0.174 & $(0.007)$ \\
\hline & 2 & -0.013 & $(0.011)$ & -0.008 & $(0.011)$ & -0.006 & $(0.012)$ & 0.000 & $(0.011)$ \\
\hline \multirow[t]{2}{*}{ IM to BR } & 1 & 0.000 & $(0.000)$ & 0.000 & $(0.000)$ & 0.000 & $(0.000)$ & 0.000 & $(0.000)$ \\
\hline & 2 & 0.024 & $(0.012)$ & 0.022 & $(0.011)$ & 0.029 & $(0.012)$ & 0.027 & $(0.012)$ \\
\hline \multirow[t]{2}{*}{ BR to PR } & 1 & 0.000 & $(0.000)$ & 0.064 & $(0.014)$ & 0.000 & $(0.000)$ & 0.072 & $(0.014)$ \\
\hline & 2 & 0.011 & $(0.013)$ & 0.004 & (0.014) & 0.017 & $(0.014)$ & 0.014 & $(0.014)$ \\
\hline \multirow[t]{2}{*}{ BR to IM } & 1 & 0.000 & $(0.000)$ & 0.041 & $(0.013)$ & 0.000 & $(0.000)$ & 0.044 & $(0.013)$ \\
\hline & 2 & 0.037 & $(0.015)$ & 0.028 & $(0.015)$ & 0.045 & $(0.016)$ & 0.037 & $(0.015)$ \\
\hline \multirow[t]{2}{*}{$\mathrm{BR}$ to $\mathrm{BR}$} & 1 & 0.235 & $(0.010)$ & 0.222 & (0.009) & 0.237 & $(0.010)$ & 0.222 & $(0.009)$ \\
\hline & 2 & -0.045 & $(0.016)$ & -0.042 & $(0.016)$ & -0.039 & $(0.017)$ & -0.037 & $(0.016)$ \\
\hline
\end{tabular}

Notes:

The factorisation columns correspond to the Cholesky factorisation of the covariance matrix with ordering

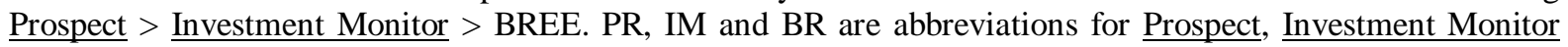
and BREE, respectively. Standard errors are in parentheses. 
Table A3.1 Are capex revisions independent?

\begin{tabular}{|c|c|c|c|c|c|c|c|c|c|}
\hline \multirow{2}{*}{$\begin{array}{c}\text { Other sources } \\
\text { (1) }\end{array}$} & \multicolumn{3}{|c|}{ Prospect } & \multicolumn{3}{|c|}{ Investment Monitor } & \multicolumn{3}{|c|}{ BREE } \\
\hline & $\begin{array}{c}\text { Update } \\
(2)\end{array}$ & $\begin{array}{c}\text { No Update } \\
\text { (3) } \\
\end{array}$ & $\begin{array}{c}\text { Total } \\
(4) \\
\end{array}$ & $\begin{array}{c}\text { Update } \\
(5)\end{array}$ & $\begin{array}{c}\text { No Update } \\
(6)\end{array}$ & $\begin{array}{c}\text { Total } \\
(7) \\
\end{array}$ & $\begin{array}{c}\text { Update } \\
(8)\end{array}$ & $\begin{array}{c}\text { No Update } \\
(9) \\
\end{array}$ & $\begin{array}{c}\text { Total } \\
(10) \\
\end{array}$ \\
\hline \multicolumn{10}{|c|}{ A. Observed (number) } \\
\hline Update & 41 & 138 & 179 & 50 & 114 & 164 & 66 & 40 & 106 \\
\hline No Update & 11 & 92 & 103 & 26 & 92 & 118 & 84 & 92 & 176 \\
\hline Total & 52 & 230 & 282 & 76 & 206 & 282 & 150 & 132 & 282 \\
\hline \multicolumn{10}{|c|}{ B. Observed (\%) } \\
\hline No Update & 3.90 & 32.62 & 36.52 & 9.22 & 32.62 & 41.84 & 29.79 & 32.62 & 62.41 \\
\hline Total & 18.44 & 81.56 & 100.00 & 26.95 & 73.05 & 100.00 & 53.19 & 46.81 & 100.00 \\
\hline \multicolumn{10}{|c|}{ C. Expected (\%) } \\
\hline Update & 11.70 & 51.77 & 63.48 & 15.67 & 42.48 & 58.16 & 19.99 & 17.59 & 37.59 \\
\hline No Update & 6.74 & 29.79 & 36.52 & 11.28 & 30.57 & 41.84 & 33.20 & 29.21 & 62.41 \\
\hline Total & 5.31 & 1.20 & 6.51 & 1.94 & 0.72 & 2.66 & 2.85 & 3.22 & 6.07 \\
\hline
\end{tabular}

The $\chi^{2}$-test statistics in panel D are 6.51, 2.66 and 6.07 for Prospect, Investment Monitor and BREE, respectively. These are formed from the rounded expectations recorded in panel B. The $\chi^{2}$-statistics implied by the unrounded expectations are 6.50, 2.49, and 5.61 (same order). 